PNNL-18196

U.S. DEPARTMENT OF

Prepared for the U.S. Department of Energy

under Contract DE-AC05-76RL01830

\title{
Hanford Site Secondary Waste Roadmap
}

January 2009

Prepared for

U. S. Department of Energy

Office of Environmental Management

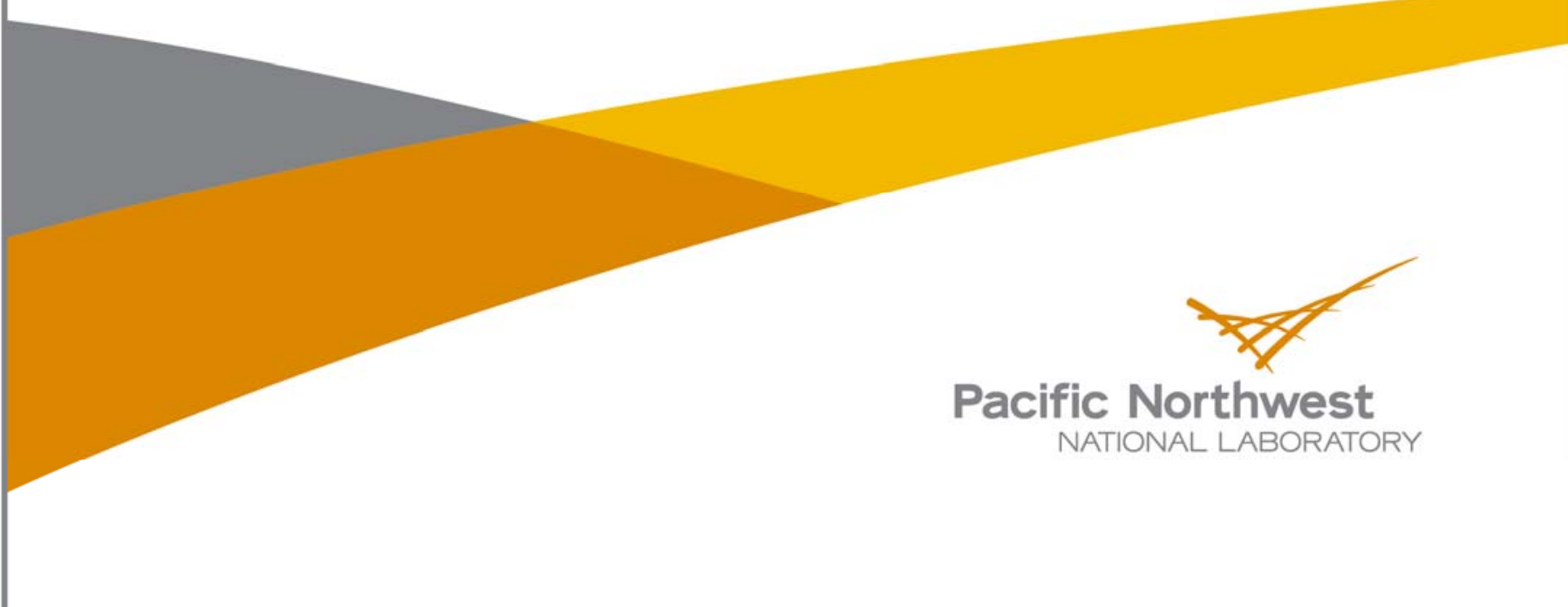




\title{
DISCLAIMER
}

This report was prepared as an account of work sponsored by an agency of the United States Government. Neither the United States Government nor any agency thereof, nor Battelle Memorial Institute, nor any of their employees, makes any warranty, express or implied, or assumes any legal liability or responsibility for the accuracy, completeness, or usefulness of any information, apparatus, product, or process disclosed, or represents that its use would not infringe privately owned rights. Reference herein to any specific commercial product, process, or service by trade name, trademark, manufacturer, or otherwise does not necessarily constitute or imply its endorsement, recommendation, or favoring by the United States Government or any agency thereof, or Battelle Memorial Institute. The views and opinions of authors expressed herein do not necessarily state or reflect those of the United States Government or any agency thereof.

\author{
PACIFIC NORTHWEST NATIONAL LABORATORY \\ operated by \\ BATTELLE \\ for the \\ UNITED STATES DEPARTMENT OF ENERGY \\ under Contract DE-ACO5-76RL01830
}

Printed in the United States of America
Available to DOE and DOE contractors from the
Office of Scientific and Technical Information,
P.O. Box 62, Oak Ridge, TN 37831-0062;
ph: (865) 576-8401
fax: (865) 5765728
email: reports@adonis.osti.gov

\footnotetext{
Available to the public from the National Technical Information Service, U.S. Department of Commerce, 5285 Port Royal Rd., Springfield, VA 22161 ph: (800) 553-6847 fax: (703) 605-6900

email: orders@nits.fedworld.gov online ordering: http://www.ntis.gov/ordering.htm
} 


\section{Hanford Site Secondary Waste Roadmap}

January 2009

Prepared for

U. S. Department of Energy

Office of Environmental Management 


\section{Summary}

The U.S. Department of Energy (DOE) is making plans to dispose of 54 million gallons of radioactive tank wastes at the Hanford Site near Richland, Washington. The high-level wastes and low-activity wastes will be vitrified and placed in permanent disposal sites. However, there will also be secondary wastes that will be generated during this process, and these need to be processed and disposed of also. There are significant uncertainties associated with the processing of these secondary wastes, and the Department of Energy Office of Waste Processing sponsored a meeting to develop a roadmap to outline the steps necessary to design the secondary waste forms. Representatives from DOE, the U.S. Environmental Protection Agency, the Washington State Department of Ecology, the Oregon Department of Energy, Nuclear Regulatory Commission, technical experts from the DOE national laboratories, academia, and private consultants convened in Richland, Washington, during the week of July 21-23, 2008, to participate in a workshop to identify the risks and uncertainties associated with the treatment and disposal of the secondary wastes and to develop a roadmap for addressing those risks and uncertainties. This report describes the results of the roadmap meeting in Richland.

Processing of the tank wastes will generate secondary wastes, including routine solid wastes and liquid process effluents. Solid wastes from the waste treatment facilities may include failed equipment, decontamination wastes, high-efficiency particulate air filters, carbon absorption beds, silver mordenite iodine sorbent beds, and spent ion exchange resin. Liquid wastes may include process condensates and scrubber/off gas treatment liquids from the thermal waste treatment processes. After packaging, the solid secondary wastes will be sent to the Integrated Disposal Facility (IDF) for disposal. The liquid-effluent secondary wastes will be sent to the Effluent Treatment Facility (ETF) for further treatment and disposal, either as treated liquid effluent under the ETF State Wastewater Discharge Permit or as solidified liquid effluents under the Dangerous Waste Permit for disposal at the IDF. The secondary waste roadmap workshop focused on the waste streams that contained the largest fractions of the ${ }^{129} \mathrm{I}$ and ${ }^{99} \mathrm{Tc}$ that the IDF risk assessment analyses were showing to have the largest contribution to the estimated IDF disposal impacts to groundwater. Thus, the roadmapping effort was to focus on the scrubber/off-gas treatment liquids with ${ }^{99}$ Tc to be sent to ETF for treatment and solidification and the silver mordenite and carbon beds with the captured ${ }^{129}$ I to be packaged and sent to the IDF.

At the highest level, the secondary waste roadmap includes elements addressing regulatory and performance requirements, waste composition, preliminary waste form screening, waste form development, process design and support, and validation. The regulatory and performance requirements activity will provide the secondary waste-form performance requirements. The waste-composition activity will provide workable ranges of secondary waste compositions and formulations for simulants and surrogates. Preliminary waste form screening will identify candidate waste forms for immobilizing the secondary wastes. The waste form development activity will mature the waste forms, leading to a selected waste form(s) with a defensible understanding of the long-term release rate and input into the critical decision process for a secondary waste treatment process/facility. The process and design support activity will provide a reliable process flowsheet and input to support a robust facility design. The validation effort will confirm that the selected waste form meets regulatory requirements. The final outcome of the implementation of the secondary waste roadmap is the compliant, effective, timely, and cost-effective disposal of the secondary wastes. 
At the next level of the roadmap, the primary activities are further divided into sub-activities, and programmatic, regulatory, and technical risks and uncertainties for each sub-activity are identified. The work necessary to address the programmatic, regulatory, and technical risks and uncertainties identified through the Secondary Waste Roadmap Workshop are assembled into several program needs elements.

Programmatic/Regulatory needs include:

- Select and deploy Hanford tank waste supplemental treatment technology

- Provide treatment capability for secondary waste streams from tank waste treatment

- Develop consensus on secondary waste form acceptance.

Technology needs include:

- Define secondary waste composition ranges and uncertainties

- Identify and develop waste forms for secondary waste immobilization and disposal

- Develop test methods to characterize secondary waste form performance.

Details for each of these program elements are provided.

In the document that follows, the introduction (Section 1) provides background information regarding the Hanford Site, the waste-disposal program being conducted there, and the process followed to develop the secondary waste roadmap. Section 2 provides the overarching roadmap diagram, and Section 3 describes the key dimensions and level 2 roadmaps addressed by the workshop. Section 4 describes the need elements for addressing secondary waste risks and uncertainties, and the appendices provide background information for the roadmap meetings (Appendix A), regulatory drivers (Appendix B), waste composition (Appendix C), and waste forms (Appendix D). 


\section{Acronyms}

\begin{tabular}{|c|c|}
\hline AEA & Atomic Energy Agency \\
\hline ALARA & as low as reasonably achievable \\
\hline ANL & Argonne National Laboratory \\
\hline ASTM & ASTM International, a consensus standards organization \\
\hline AWT-x & label for alternate waste treatment needs \\
\hline $\mathrm{BBI}$ & best basis inventory \\
\hline BNI & Bechtel National, Inc. \\
\hline CD & critical decision \\
\hline CERCLA & Comprehensive Environmental Response, Compensation, and Liability Act \\
\hline COC & constituent of concern \\
\hline CUA & The Catholic University of America \\
\hline DOE & U.S. Department of Energy \\
\hline DQ-X & label for data quality needs \\
\hline DQO & data quality objectives \\
\hline EIS & environmental impact statement \\
\hline EM & Office of Environmental Management (DOE) \\
\hline EPA & U.S. Environmental Protection Agency \\
\hline ETF & Effluent Treatment Facility \\
\hline DI-X & label for understanding disposal interaction needs \\
\hline GW & groundwater \\
\hline HDW & Hanford Defined Waste model \\
\hline HEPA & high-efficiency particulate air \\
\hline HLW & high-level waste \\
\hline HTWOS & Hanford Tank Waste Operations Simulator \\
\hline IDF & Integrated Disposal Facility \\
\hline IHLW & immobilized high-level waste \\
\hline ILAW & immobilized low-activity waste \\
\hline INL & Idaho National Laboratory \\
\hline LAW & low-activity waste \\
\hline LBNL & Lawrence Berkeley National Laboratory \\
\hline LDR & land disposal restriction \\
\hline NRC & U.S. Nuclear Regulatory Commission \\
\hline ORNL & Oak Ridge National Laboratory \\
\hline ORP & Office of River Protection \\
\hline
\end{tabular}




\begin{tabular}{|c|c|}
\hline PA & performance assessment \\
\hline PAM-X & label for performance assessment modeling needs \\
\hline PCT & product consistency test (Standard Test Method ASTM C1285, current revision) \\
\hline PDS-X & label for process and design support needs \\
\hline POG & point of generation \\
\hline PNNL & Pacific Northwest National Laboratory \\
\hline$P V-x$ & label for performance validation needs \\
\hline QA & quality assurance \\
\hline QC & quality control \\
\hline RBT & risk budget tool \\
\hline RBT-X & label for risk budget tool needs \\
\hline RCRA & Resource Conservation and Recovery Act \\
\hline $\mathrm{RR}-\mathrm{x}$ & label for regulatory requirements needs \\
\hline R\&T & research and technology \\
\hline SIM-X & label for waste simulant needs \\
\hline SPFT & single-pass flow through (Standard Test Method ASTM C1662, current revision) \\
\hline SRNL & Savannah River National Laboratory \\
\hline SRS & Savannah River Site \\
\hline SW & solid waste \\
\hline TC & tank closure \\
\hline TI-X & label for tank inventory needs \\
\hline TM-X & label for release mechanism testing needs \\
\hline TRA & technology readiness assessment \\
\hline WAC & waste acceptance criteria \\
\hline WAC-X & label for waste acceptance criteria needs \\
\hline WC-X & label for waste composition needs \\
\hline WF-X & label for waste form development needs \\
\hline WF-PA-X & label for waste form development/performance assessment needs \\
\hline WFA-X & label for waste form aging needs \\
\hline WFS-X & label for waste form screening needs \\
\hline WR-x & label for waste retrieval needs \\
\hline WTP & Waste Treatment and Immobilization Plant \\
\hline WTP-x & label for WTP waste treatment needs \\
\hline
\end{tabular}




\section{Contents}

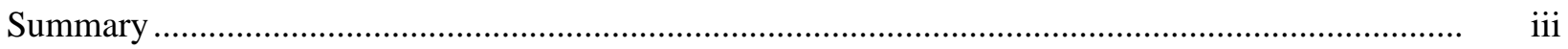

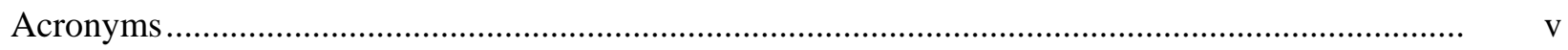

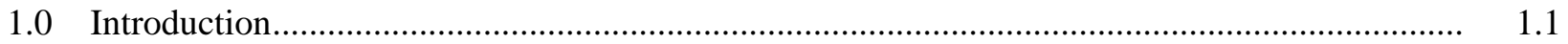

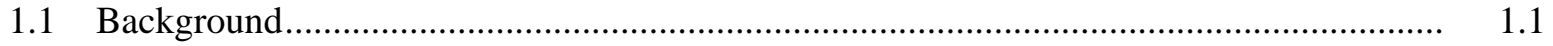

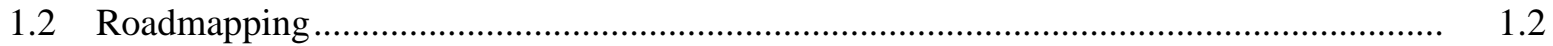

1.3 Secondary Waste Roadmap Development........................................................................ 1.3

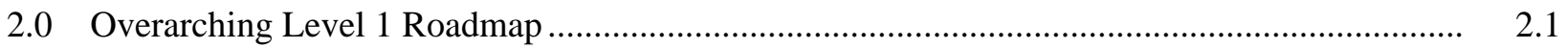

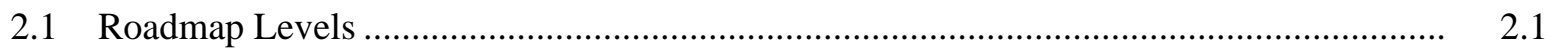

2.2 Level 1 Primary Activities....................................................................................... 2.1

2.3 Level 1 Sequencing, Primary Outcomes, and Key Feedback Loops ................................ 2.3

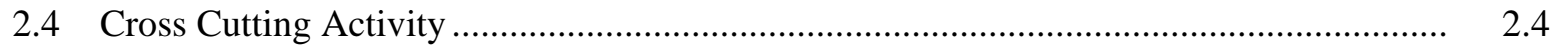

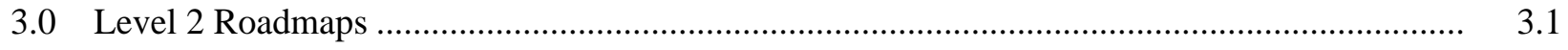

3.1 Regulatory Requirements .................................................................................. 3.1

3.1.1 Regulatory Requirements Sub-Activities ............................................................ 3.1

3.1.2 Regulatory Requirements Sequencing............................................................

3.1.3 Risks and Needs for Each Regulatory Requirements Sub-Activity....................... 3.2

3.2 Waste Composition.............................................................................................. 3.5

3.2.1 Waste Composition Sub-Activities...................................................................... 3.5

3.2.2 Waste Composition Sequencing ....................................................................... 3.5

3.2.3 Risks and Needs for Each Waste Composition Sub-Activity ................................. 3.6

3.3 Preliminary Waste Form Screening ............................................................................... 3.9

3.3.1 Waste Form Screening Sub-Activities.............................................................. 3.9

3.3.2 Preliminary Waste Form Screening Sequencing ............................................... 3.9

3.3.3 Risks and Needs for Each Waste Form Screening Sub-Activity ........................... 3.10

3.4 Waste Form Development ............................................................................................

3.4.1 Waste Form Development Sub-Activities ......................................................... 3.13

3.4.2 Waste Form Development Sequencing............................................................... 3.13

3.4.3 Risks and Needs for Each Waste Form Development Sub-Activity …................... 3.14

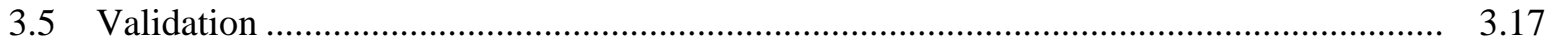

3.5.1 Validation Sub-Activities ................................................................................ 3.17

3.5.2 Validation Sequencing............................................................................... 3.17

3.5.3 Risks and Needs for Validation .................................................................. 3.17

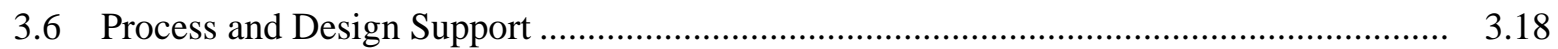

3.6.1 Process and Design Support Sub-Activities ...................................................... 3.18 
3.6.2 Design Support Sequencing......................................................................... 3.18

3.6.3 Risks and Needs for Process and Design Support .............................................. 3.19

4.0 Program Need Elements to Address Secondary Waste Risks and Uncertainties........................ 4.1

4.1 Select and Deploy Hanford Tank Waste Supplemental Treatment Technology ............... $\quad 4.1$

4.2 Provide Treatment Capability for Secondary Waste Streams from Tank Waste

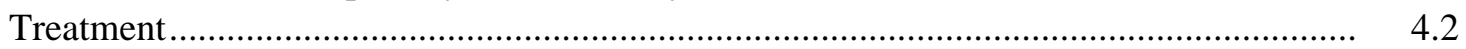

4.3 Develop Consensus on Secondary Waste Form Acceptance.............................................

4.4 Define Secondary Waste Composition Ranges and Uncertainties .................................... 4.2

4.5 Identify and Develop Waste Forms for Secondary Waste Immobilization and Disposal .. 4.3

4.6 Develop Test Methods for Secondary Waste Form Characterization ............................... 4.5

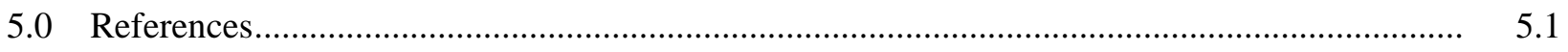

Appendix A: Secondary Waste Roadmap Workshop Agenda........................................................ A.1

Appendix B: Secondary Waste Treatment and Disposal Needs Summary—Regulatory Drivers........ B.1

Appendix C: Secondary Waste Treatment and Disposal Needs Summary—Waste Composition ....... C.1

Appendix D: Secondary Waste Treatment and Disposal Needs Summary—Waste Form.................. D.1 


\section{Figures}

2.1. Level 1—Overarching Secondary Waste Roadmap .............................................................. 2.2

3.1. Level 2-Regulatory Requirements.................................................................................. 3.4

3.2. Level 2-Waste Composition ......................................................................................... 3.8

3.3. Level 2-Preliminary Waste Form Screening ......................................................................... 3.12

3.4. Level 2-Waste Form Development ..................................................................................... 3.16

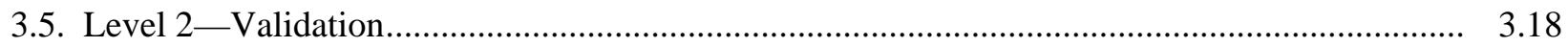

3.6. Level 2_Process and Design Support.................................................................................. 3.19

\section{Tables}

1.1. Secondary Waste Roadmap Advisory Panel.......................................................................... 1.4

1.2. Regulatory Drivers Working Group Participants...................................................................... 1.4

1.3. Waste Composition Working Group Participants ........................................................................

1.4. Waste Form Working Group Participants.................................................................................... 1.5

3.1. Secondary Waste Treatment and Disposal Needs Summary Tables Legend for Appendix B...... 3.3

3.2. Secondary Waste Treatment and Disposal Needs Summary Legend for Appendix C ................ 3.7

3.3. Secondary Waste Treatment and Disposal Needs Summary Legend for Appendix D ................ 3.11 


\subsection{Introduction}

The process of immobilizing Hanford's 54 million gallons of radioactive tank wastes will generate secondary wastes that will need treatment and disposal. Liquid secondary waste from the treatment of tank waste is expected to be processed through the Effluent Treatment Facility (ETF) with a proposed new solidification treatment unit and stabilized in a grout-encapsulated solid waste form to be disposed of in the Integrated Disposal Facility (IDF). Risk assessments indicate that ${ }^{99} \mathrm{Tc}$ is the key contaminant for groundwater impacts (with ${ }^{129}$ I also of concern). However, there are significant uncertainties associated with secondary waste and these predicted groundwater impacts. There are also significant uncertainties associated with the treatment and disposal of solid secondary wastes associated with treatment of tank waste at Hanford.

At the request of the U.S. Department of Energy (DOE) Office of River Protection (ORP), DOE's Office of Waste Processing (DOE EM-21) agreed to sponsor a meeting to develop a roadmap to outline the steps necessary to design the secondary waste form to resolve uncertainties associated with disposal of secondary waste from treatment of tank waste at Hanford. Representatives from DOE, the U.S. Environmental Protection Agency (EPA), the Washington State Department of Ecology (Ecology), the Oregon Department of Energy, Nuclear Regulatory Commission, technical experts from the DOE national laboratories, academia, and private consultants convened in Richland, Washington, during the week of July 21-24, 2008, to participate in a workshop to identify the risks and uncertainties associated with the treatment and disposal of the secondary wastes and to develop a roadmap for addressing those risks and uncertainties. The objective of the work is to develop a roadmap outlining the technical and programmatic steps necessary to design, develop, demonstrate, and accept a baseline waste form for the treatment and disposal of secondary wastes associated with the treatment of tank wastes at Hanford. This report presents the roadmap developed from that meeting.

\subsection{Background}

The Hanford Site in southeast Washington State has 54 million gallons of radioactive and chemically hazardous wastes stored in 177 underground tanks. Wastes have been retrieved from seven of these tanks and placed within the other remaining tanks. The wastes were generated as a result of more than 30 years of plutonium production in support of the nation's defense programs. ORP's mission is to retrieve and treat Hanford's tank waste and close the tank farms to protect the Columbia River, which marks the northern and eastern boundary of the Site. To pursue this mission, ORP, through its contractors, is constructing the Waste Treatment and Immobilization Plant (WTP) to convert the radioactive and hazardous wastes into stable glass waste forms for disposal. Supplemental treatment technologies are also being pursued to provide additional immobilization capacity for low-activity tank wastes. Within the WTP, the pretreatment facility will receive the retrieved waste from the tank farms and separate it into two treated process streams. The low-activity waste (LAW) stream is characterized as a high-volume, low-activity liquid process stream stripped of most solids and high-activity radioisotopes. The high-level waste (HLW) stream will be a much smaller volume slurry containing most of the solids, which have the high-activity isotopes, including ${ }^{137} \mathrm{Cs}$ and long-lived radioisotopes. The pretreated HLW mixture will route to the High-Level Waste Vitrification Facility, and the pretreated LAW stream will route to the Low-Activity Waste Vitrification Facility and to a supplemental treatment facility. The two WTP vitrification facilities will convert these process streams into glass, which is poured directly into stainless steel canisters. The immobilized HLW (IHLW) canisters will ultimately be disposed of offsite at a 
federal repository. The immobilized LAW (ILAW) canisters will be disposed of onsite in the IDF. ILAW glass produced in a supplemental treatment facility will also be disposed in the IDF.

In addition to the primary IHLW and ILAW glass waste forms, the processing of the tank wastes will generate secondary wastes, including routine solid wastes and liquid process effluents. Solid wastes from the waste treatment facilities may include failed equipment, decontamination wastes, high-efficiency particulate air (HEPA) filters, carbon absorption beds, silver mordenite iodine sorbent beds, and spent ion exchange resin. Liquid wastes may include process condensates and scrubber/off gas treatment liquids from the thermal waste treatment processes. After packaging, the solid secondary wastes will be sent to the IDF for disposal. The liquid-effluent secondary wastes will be sent to the Effluent Treatment Facility (ETF) for further treatment and disposal, either as treated liquid effluent under the ETF State Wastewater Discharge Permit or as solidified liquid effluents under the Dangerous Waste Permit for disposal at the IDF. An additional solidification treatment unit has been proposed for the ETF. This new treatment unit would solidify the ETF evaporator brines into a cement-based waste form for disposal.

Current flowsheet calculations for the WTP and supplemental treatment technologies estimate that approximately 92 percent of the ${ }^{99}$ Tc inventory in the tanks will be disposed of in IDF with 91.5 percent of the original inventory in the immobilized low-activity waste (ILAW) glass waste form and 0.3 percent as the solid waste form from secondary waste treatment/solidification in the ETF (Crawford et al. 2008). One processing scenario involves early immobilization of LAW in the WTP LAW vitrification facility before the pretreatment facility is operational to receive liquid effluent recycle. In this scenario, 81 percent of the ${ }^{99} \mathrm{Tc}$ in the tanks would be disposed of as ILAW glass and 11 percent would be disposed as ETF solids.

For ${ }^{129}$ I, the current flowsheet calculations estimate that 96 percent of the iodine tank inventory will be disposed of in IDF with approximately 20 percent of the inventory in ILAW glass and 76 percent as solid waste as silver mordenite iodine sorbent solids and carbon beds from WTP and solidified liquid wastes from ETF.

A risk assessment is being conducted to evaluate the impacts of disposal of ILAW, secondary wastes from treatment of the Hanford tank wastes, and other mixed low-level wastes in the IDF. The risk assessment effort has already shown the importance of contaminant inventory and release rate from the waste form(s). Key contaminants have been identified including ${ }^{99} \mathrm{Tc},{ }^{129} \mathrm{I}$, uranium, chromates, and nitrates (however, these are likely to be destroyed during vitrification). Based on current understanding of waste form performance, releases from a cement waste form with immobilized secondary wastes from ETF and the secondary solid wastes from the waste treatment facilities contribute a major fraction of the impacts of the waste disposal within IDF.

\subsection{Roadmapping}

The DOE Office of Environmental Management (DOE-EM) describes roadmapping as

... a disciplined, consensus building, analysis, solution development, and decision-making methodology that supports strategic programmatic and project planning. Roadmap preparation focuses all parties on the needs, risk-reduction alternatives, desired end-states, and the paths that will lead to efficient and timely resource investment. (DOE-EM 2000) 
Roadmapping is a tool for identifying the risks and uncertainties for both project- and program-level efforts, mapping them into solutions to reduce the risks and resolve the uncertainties, and developing the project plans to implement those solutions.

The DOE-EM office has provided draft guidance on applying roadmapping to the definition and planning of its science and technology investments (DOE-EM 2000). A four-step process, including roadmap initiation, needs assessment, technical response development, and roadmap implementation comprise the roadmapping approach. The roadmap initiation is the planning phase during which the scope, leadership, participants, and deliverables are defined. The needs assessment identifies the issues, assesses capabilities versus those issues, and identifies needs to resolve the issues and capability gaps. This secondary waste roadmapping report documents the results of the needs assessment for the Hanford secondary waste treatment. The third step in the roadmapping process is the technical response development in which alternatives are identified and the pathways to addressing the needs are developed and prioritized. The final step is roadmap implementation in which the work and activities identified as responses to the needs assessment are conducted to resolve the issues and gaps identified. The final outcome of the roadmapping process is to identify what needs to be done, when it needs to be done, and why it needs to be done. It does not identify who will do it, where to do it, or how to do it. This overall approach was implemented in developing the secondary waste roadmap.

\subsection{Secondary Waste Roadmap Development}

An advisory panel was formed to guide the secondary waste roadmap development. The panel members identified in Table 1.1 were selected as representatives of DOE, the national laboratories, regulators/regulatory background, and academia.

In defining the scope for the roadmapping effort, the panel examined flowsheet information on the various secondary waste streams from the tank waste treatment processes and focused the scope on those secondary waste streams that contained the largest fractions of ${ }^{129}$ I and ${ }^{99}$ Tc that the IDF risk assessment analyses were showing to have largest contribution to the estimated IDF disposal impacts to groundwater. Thus, the roadmapping effort was to focus on the scrubber/off-gas treatment liquids with ${ }^{99} \mathrm{Tc}$ to be sent to ETF for treatment and solidification and the silver mordenite and carbon beds with the captured ${ }^{129}$ I.

A facilitated workshop was organized to identify the programmatic, regulatory, and technical risks and uncertainties associated with the secondary waste treatment and disposal. The workshop participants, selected by the advisory panel, were assigned to one of three working groups: Regulatory Drivers Group, Waste-Composition Group, or Waste Form Group. The participants for the Regulatory Drivers Group (Table 1.2) were selected for their knowledge and experience with regulatory issues associated with waste treatment and disposal at Hanford. Participants for the Waste Composition Group (Table 1.3) were selected for their experience with the Hanford Tank Farms, Waste Treatment Plant and ETF flowsheets, and iodine and technetium process chemistry. Participants for the Waste Form Group (Table 1.4) were selected for their experience with low-level waste stabilization and immobilization forms, waste form testing, and waste disposal system performance assessments (PAs). 
Table 1.1. Secondary Waste Roadmap Advisory Panel

\begin{tabular}{lll}
\hline Role & Participant & Affiliation \\
\hline Lead & Moses Jaraysi & CH2M HILL \\
Panel & Jim Honeyman & CH2M HILL \\
Panel & David Esh & Nuclear Regulatory Commission \\
Panel & David Kosson & Vanderbilt University \\
Panel & Ben Harp/Billie Mauss & DOE-ORP \\
Panel & Jeff Griffin & Savannah River National Laboratory (SRNL) \\
Panel & Steve Krahn & DOE-EM \\
Panel & Tom Brouns & Pacific Northwest National Laboratory (PNNL) \\
Panel & Suzanne Dahl/Ed Fredenburg & Washington State Department of Ecology \\
\hline
\end{tabular}

Table 1.2. Regulatory Drivers Working Group Participants

\begin{tabular}{cll}
\hline Role & Participant & Affiliation \\
\hline Lead & Moses Jaraysi & CH2M HILL \\
Facilitator & Elizabeth McManus & Ross \& Associates \\
& David Esh & Nuclear Regulatory Commission \\
& Dave Bartus & Environmental Protection Agency \\
& Brenda Becker-Khaleel & Washington State Department of Ecology \\
& Bud Derrick & Washington State Department of Ecology \\
& Suzanne Dahl & Washington State Department of Ecology \\
& Kelly Elsethagen & Washington State Department of Ecology \\
& Dirk Dunning & Oregon Department of Energy \\
& Linda Lehman & CH2M HILL \\
& Tom Brouns & PNNL \\
& Steve Krahn & DOE-HQ \\
\hline
\end{tabular}

Table 1.3. Waste Composition Working Group Participants

\begin{tabular}{cll}
\hline Role & Participant & Technical Area \\
\hline Lead & Jim Honeyman (CH2M HILL) & Tank Farms \\
Facilitator & Elizabeth McManus (Ross \& Associates) & Facilitator \\
& Gary Smith (PNNL) & WTP Flowsheets, Simulants \\
& Scott Saunders (Bechtel National, Inc., BNI) & WTP Flowsheets \\
& Randy Scheele (PNNL) & Iodine chemistry, simulants, \\
& David Shuh (Lawrence Berkeley National Laboratory & Tc chemistry, Process \\
& [LBNL]) & Chemistry \\
& Steve Agnew (Consultant) & Radionuclide/Waste Chemistry \\
& Kristi Lueck (Fluor) & ETF Treatment \\
& Robbie Biyani (Ecology) & Regulatory Compliance \\
& Jerry Yokel (Ecology) & Regulatory Compliance \\
Ed Fredenburg (Ecology) & Regulatory Compliance \\
\hline
\end{tabular}


Table 1.4. Waste Form Working Group Participants

\begin{tabular}{cll}
\hline \multicolumn{1}{c}{ Role } & \multicolumn{1}{c}{ Participant } & \multicolumn{1}{c}{ Technical Area } \\
\hline Lead & Larry Bagaasen (PNNL) & Materials, Waste Forms, Supplemental Treatment \\
Facilitator & Elizabeth McManus & Facilitator \\
& Joe Westsik (PNNL) & Low-Temperature Immobilization \\
& Denis Strachan (PNNL) & Waste Form Testing \& Performance \\
& Christine Langton (SRNL) & Cementitious Materials \\
& Jeff Serne (PNNL) & Waste Form Performance, Radionuclide Transport \\
& Larry Lockrem (CH2M HILL) & Waste Form Testing \\
Fred Mann (CH2M HILL) & Performance Assessment \\
David Kosson/Kevin Brown & Waste Form Testing, Performance, Assessment \\
& (Vanderbilt University) & \\
Dave Maloney (CH2M HILL) & Waste Form Testing \\
Brad Mason & Steam Reforming Mineral Waste Form \\
Mike Grutzeck (Pennsylvania & Hydroceramic Cement \\
State University) & \\
Arun Wagh (Argonne National & Ceramicrete Phosphate Ceramic \\
Laboratory [ANL]) & \\
Ian Pegg (The Catholic University & Duralith Geopolymer \\
of America [CUA]) & \\
Jim Honeyman (CH2M HILL) & Tank Farms Operations \\
Robbie Biyani (Ecology) & Regulatory Compliance \\
Jerry Yokel (Ecology) & Regulatory Compliance \\
Ed Fredenburg (Ecology) & Regulatory Compliance \\
\hline
\end{tabular}

The Secondary Waste Roadmap workshop was held July 21-23, 2008, in Richland, WA. The workshop agenda is provided in Appendix A. Following background briefings, the working groups met to identify the risks and uncertainties in their particular areas of focus.

The Regulatory Group considered

- Land disposal restrictions and drinking water standards

- WTP and ETF permit conditions and DOE orders

- Waste form performance

- Waste form characteristics

The Waste Composition Group considered

- Tank inventory

- LAW treatment options

- Tc and I path through WTP and Supplemental Treatment flowsheets

- Tc and I surrogates

- Secondary waste simulants.

And the Waste Form Group considered

- Waste form selection

- Contaminant release mechanisms 
- Testing methodologies to determine waste form performance

- Demonstration, verification, and monitoring to validate waste form performance

- Waste form component interactions with disposal system and vadose zone

- Data and modeling requirements for assessing long-term performance.

The deliberations of the working groups were summarized in tables that 1) identify the risks and uncertainties with each regulatory, technical, or programmatic area, 2) describe in more detail the specific need, 3) list key inputs required to address the need, and 4) describe the expected outcomes. The secondary waste treatment and disposal needs summary tables for the Regulatory Drivers, Waste Composition, and Waste Form working groups are provided in Appendices B, C, and D, respectively.

Following the 3-day workshop, a smaller roadmapping team composed of the available advisory panel members or their delegates, the group leaders, two process-chemistry experts, and the workshop facilitator met to examine the risks and uncertainties identified by the workshop participants and to organize them into related groups of needs and lay out the technical sequencing of activities to address those needs. The group used an exercise with movable hexagons to organize all the risks and uncertainties identified during the workshop into "story lines" to describe what work needed to happen to navigate and manage risks and make effective decisions about secondary waste. The result of this exercise was a series of sequenced activities and sub-activities, key decision points, and outcomes and feedback loops. Their related risks and uncertainties that form the basis for the secondary waste roadmap were also included. These activities and sub-activities as well as the sequencing and dependencies are described in the following sections. 


\subsection{Overarching Level 1 Roadmap}

The end "destination" of the secondary waste roadmap was discussed in the workshop and established as a "Compliant, Effective, Timely, Cost-Effective Secondary Waste Disposal." The first 3 days of the workshop were structured to identify all of the risks and uncertainties associated with getting to this destination while the fourth day focused on arranging these risks into sets of activities that could be logically sequenced to generate the roadmap to this destination. The roadmapping group on the fourth day determined that roadmaps with different levels of detail would be the most effective way to arrange the products of the workshop.

\subsection{Roadmap Levels}

Part of the roadmap structure was established by the advisory panel to facilitate the organization of the workshop. Regulatory drivers, secondary waste composition, and waste form were three primary activities that needed to be addressed in a secondary waste roadmap. The roadmapping team determined that a Level 1 overarching road map should include a primary activity related to regulatory drivers and a primary activity related to waste composition, but the waste from efforts needed to be broken into a few primary activities to be useful. These primary activities were sequenced to generate the Level 1 roadmap shown in Figure 2.1, and all the identified risks were coarsely divided between the different primary activities. The Level 1 primary activities and sequencing efforts are discussed in this section.

The next step in the process was to divide each of the primary activities into the number of sub-activities necessary to collect all the identified risks for a given primary activity into meaningful groups. These sub-activities and the associated groups of risks/needs were then sequenced to generate the Level 2 roadmaps discussed in Section 3.

There were additional discussions related to a Level 3 roadmap that would define the work breakdown structure necessary to address the needs in each sub-activity. There was general agreement that this would be a useful activity but was beyond the scope of this workshop.

\subsection{Level 1 Primary Activities}

The roadmapping group determined that the secondary waste form activity should be broken into a screening activity, a development activity, a validation activity, and a design support activity. After splitting the waste form into these four primary activities, there were six primary activities that made up the Level I overarching roadmap:

- Identification of applicable regulatory and performance requirements

- Defining the envelope of secondary waste compositions

- Conducting a preliminary waste-form screening process that narrows the list of potential secondary waste form candidates to one or a few waste forms that merit additional investment

- Development of the selected waste forms to determine the controlling release mechanism in order to optimize waste form performance for the expected secondary waste envelope and to develop models to predict waste form performance over PA time periods

- Validation of waste form performance in disposal conditions and post disposal

- Supply process and design support information for constructing the secondary waste treatment facility 


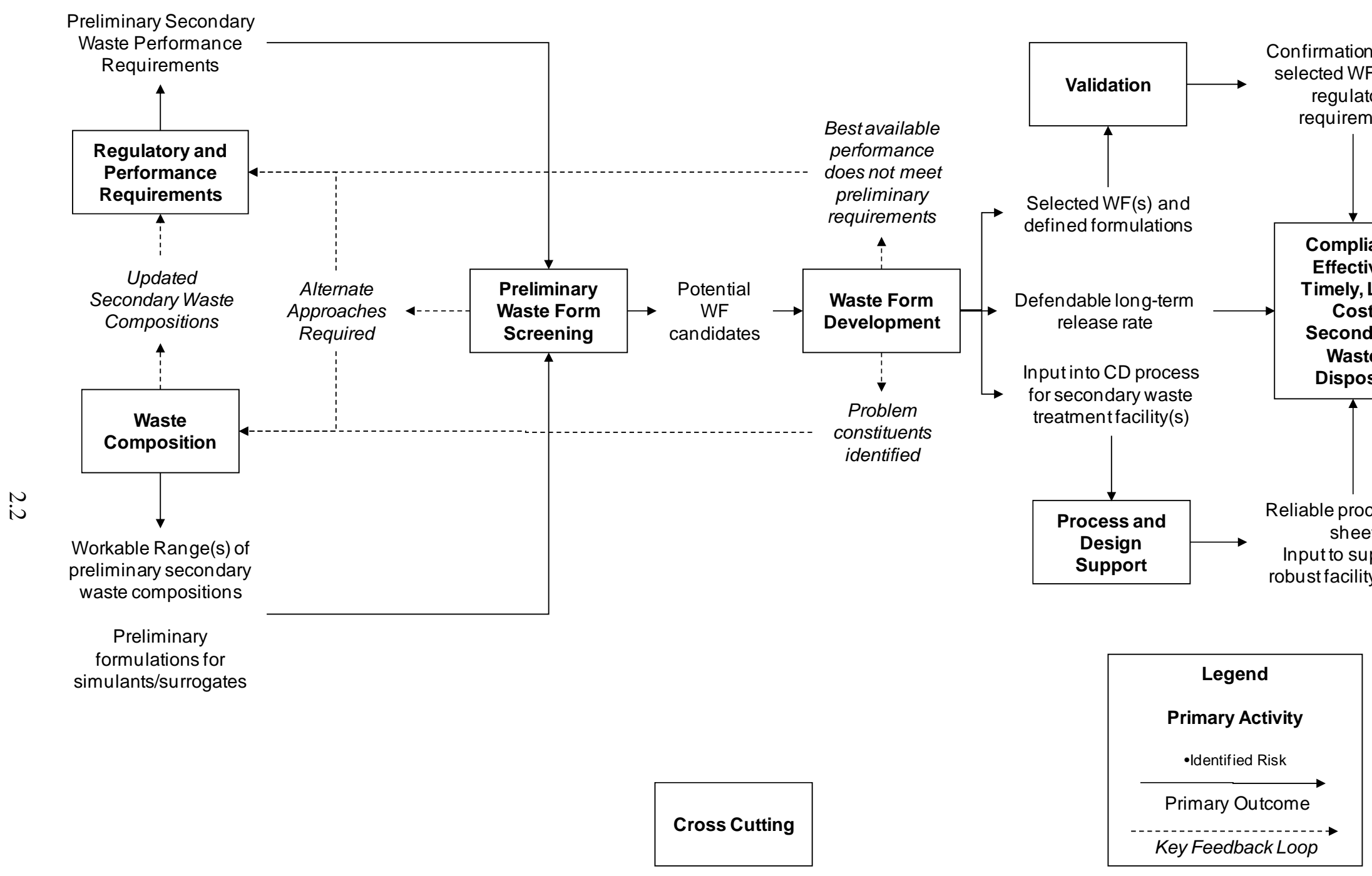

Figure 2.1. Level 1 -Overarching Secondary Waste Roadmap 


\subsection{Level 1 Sequencing, Primary Outcomes, and Key Feedback Loops}

After determining the list of primary activities, the next step in the process was to establish the sequencing of these activities. To facilitate the sequencing, primary outcomes and key feedback loops were generated for each primary activity. The resulting Level 1 overarching road map is shown in Figure 2.1.

The regulatory and waste-composition activities could start independently of each other. The regulatory requirements are somewhat dependent on the hazardous constituents that make it into the secondary waste stream, but assuming that some of the constituents in the tank inventories make it to the secondary waste stream allows the regulatory activity to generate preliminary secondary-waste performance requirements. The waste composition activity can be started using existing information, but will initially have large uncertainties due to tank inventory, retrieval, flowsheet, and alternate technology selection uncertainties. The primary outcomes from this activity are a workable range of preliminary secondary waste compositions and preliminary formulations for simulants. As decisions are made and the primary treatment technology flowsheets are finalized, changes to the range of potential secondary wastes may generate a feedback loop that will require a refinement in the regulatory requirements.

The outcomes of the regulatory and waste-composition activities feed the preliminary waste form screening process. This screening process is necessary because there was a clear desire to be broad in the consideration of possible waste forms but there are not sufficient resources to do extensive development on all possible candidates. The primary outcome of this screening activity is a short list of potential candidates that merit further investment. This screening activity could point out that there are no secondary waste form candidates that have the potential to meet all waste performance requirements for the full range of waste streams. This possibility is covered by the feedback loop to the regulatory requirements and waste-composition activities.

The list of potential waste form candidates feeds the waste form development activity. The waste form development portion of the roadmap makes an additional investment in one or more candidate waste forms to better understand the characteristics of the waste form that control contaminant release. This understanding is necessary to generate the main outcomes of this activity: a single or set of high performing waste forms with defined formulations, a defendable long-term release rate to support a decision for secondary waste disposal, and input into the critical decision process to support design and construction of a secondary waste treatment facility. This waste form development activity may determine that the best available performance does not meet all the preliminary waste performance requirements, which would lead to a feedback loop to the regulatory activity. This activity may also discover that specific secondary waste constituents are problematic for the secondary waste form and might be handled differently in the primary waste treatment processes. This possibility is shown as a feedback loop to the secondary waste-composition activity.

The selected secondary waste forms feed the validation activity. This activity verifies that the waste form performs in the disposal environment as predicted by the development activity. The primary outcome from this activity is a confirmation that the waste form meets regulatory requirements. 
The critical decision input feeds the process and design support activity. The primary outcome from this activity is a reliable process flow sheet that supports a robust facility design. Although feedback loops from the validation and process/design support activities are possible, they are not shown on the overarching roadmap in Figure 2.1 because these activities should only be initiated after there is a high level of confidence that the selected waste form will meet all requirements and support a reliable process flow sheet.

\subsection{Cross Cutting Activity}

Several general risks were identified in the workshop that could be applied to any of the primary activities. Rather than listing these risks for each activity, a crosscutting activity was added to Figure 2.1 to cover these items. The data quality (DQ) risk DQ-1 and risks associated with uncertainty management and decision acceptance were placed in the cross-cutting activity. These risks generally related to making sure that data were collected at a quality level (e.g., accuracy, precision, and detection limit) that supports the drivers for those data. These cross-cutting risks also related to overall acceptance of the decisions generated from each activity and appropriate treatment of uncertainty at different points in the roadmap.

Data quality objective (DQO) studies were identified as the primary need necessary to address the data quality risks. Working groups that included all the stakeholders, decision makers, and implementing contractors were identified as a need to facilitate acceptance of final secondary waste decisions. An overall program strategy for dealing with uncertainty was identified as a need to allow for a balance between making progress with the best available data while maintaining sufficient program flexibility to adjust to reductions in uncertainties that will naturally occur as the primary Hanford tank waste treatment processes mature. 


\subsection{Level 2 Roadmaps}

This section describes the key dimensions addressed by the workshop, including the regulatory requirements, waste composition, preliminary waste form screening (WFS), waste form development, validation, and process design support with their sub-activities, sequencing, risks, and needs.

\subsection{Regulatory Requirements}

A full and timely understanding of regulatory requirements is critical to efficient selection and design of a compliant waste form. Resolving risks associated with regulatory requirements is anticipated to be an iterative process where an initial understanding of standards to be addressed and regulatory drivers provides a basis for waste form development and performance assessment. These activities, along with risk budgeting work, in turn provide a basis for the development of final waste acceptance criteria. The roadmap anticipates a collaborative approach for developing regulatory requirements where the regulatory agencies work with waste form designers to understand and evaluate how to optimize waste form performance.

\subsubsection{Regulatory Requirements Sub-Activities}

The regulatory requirements risks fell into four sub-activities:

- Identification of applicable regulatory requirements and parameters

- Responding to input and findings from the waste form development Performance Assessment

- Implementation of the Hanford Risk Budget Tool (RBT)

- Development of final waste acceptance criteria.

\subsubsection{Regulatory Requirements Sequencing}

As described above, the roadmapping team anticipates that resolving risks associated with regulatory requirements will be an iterative process where an initial understanding of standards and regulatory drivers informs waste form development and performance assessment and these activities, along with risk budgeting work, in turn provide a basis for the development of final waste acceptance criteria. The resulting Regulatory Requirements Level 2 Roadmap is shown in Figure 3.1.

The sequence of activities begins with identification of standards to be addressed. This is a critical first step in setting the understanding of what regulatory requirements must be addressed. The initial list identified by the Regulatory Drivers Group is as follows:

- EPA and Ecology requirements under the Resource Conservation and Recovery Act and, in Washington State, the Hazardous Waste Management Act, including waste designation and landdisposal restriction treatment standards

- EPA and Ecology drinking water standards under the Clean Water Act, particularly with respect to verifying that the waste form is adequately protective of groundwater

- DOE and Nuclear Regulatory Commission requirements for waste determination

- DOE requirements for radioactive waste management and low-level waste disposal (DOE 1999) 
- DOE requirements for achieving as low as reasonably achievable (ALARA) standards.

Once the standards to be addressed are identified, the roadmap calls for collaborative work with regulators to develop a more refined understanding of likely requirements. This will include evaluating where standards have the potential to conflict with one another or to otherwise drive waste form development in different directions. It also will involve work to reach an understanding of how applicable standards will be applied in the specific environmental setting at Hanford and in light of preexisting contamination. Additional applicable standards may be identified as part of this dialogue. The result of this work should be a more refined understanding of likely regulatory requirements adequate to support the performance of the Waste Form Development Performance Assessment and application of the Hanford RBT. The RBT is a model for examining the cumulative risk to the vadose zone and groundwater from all waste previously disposed of in the IDF and those wastes expected to be disposed of in IDF in the future.

Feedback from the Waste Form Development Performance Assessment and application of the Hanford RBT will result in further refinement of likely regulatory requirements and identification of the driving inputs, parameters, and assumptions for developing waste acceptance criteria. The desired outcome of this process is a set of preliminary waste form requirements that can be used in waste form selection, development, and testing.

\subsubsection{Risks and Needs for Each Regulatory Requirements Sub-Activity}

The product of the first 3 days of the roadmap workshop was a group of risks and an understanding of what would be needed to address and manage risk. Table 3.1 lists the legend for the numbering of the risks in the Regulatory Group risks and uncertainties in Appendix B. On the fourth day of the workshop, the roadmapping team binned each of the risks into sets of sequenced activities that make up the secondary waste roadmap. The following sections summarize the risks and needs that were identified during the early part of the workshop and show how they were binned into the regulatory requirements sub-activities of the roadmap. In addition to the specific risks associated with each sub-activity, the timing and certainty of the Record of Decision for the Tank Closure and Solid Waste Environmental Impact Statement (TC/SW EIS) was identified as a risk for all of the regulatory requirement subactivities. An unexpected delay in TC/SW EIS timing, or an unexpected or uncertain result, could inhibit the ability to properly identify and apply regulatory requirements or could result in changes in the understanding of the regulatory status of tank waste.

\subsubsection{Regulatory Requirements}

Regulatory requirement (RR) risks RR-1 through RR-8 were binned into the sub-activity on identifying regulatory requirements and parameters. These risks generally focus on the ability to understand and gain agreement from regulators on what standards apply and how applicable standards will be implemented for secondary waste. For example, the ability to gain timely and durable agreement on applying hazardous waste designation requirements for the secondary waste to identify which waste codes and associated land-disposal restriction treatment standards apply was identified as a risk in this area. The primary need that was identified to address these risks was a mechanism that facilitated timely agreement to the applicable requirements and consistent interpretation of the standards that apply. 


\subsubsection{Waste Form Development Performance Assessment}

Waste form development/performance assessment (WF-PA) risks WF-PA-1 through WF-PA-5 were binned into the sub-activity on responding to input and findings from the Waste Form Development Performance Assessment. These risks focus on how technical imperatives may limit the ability of a secondary waste form to meet all regulatory requirements and on the potential for regulatory requirements to constrain waste form evaluation and development in ways that result in sub-optimal results. The main need identified to address these risks was a regulatory process that worked with waste form development efforts to allow potentially promising waste forms that might significantly reduce risk to continue to be evaluated even though they might not meet all requirements for all constituents of concern (COCs).

\subsubsection{Risk Budget Tool}

Risks RBT-1 and RBT-2 were binned into the sub-activity related to the implementation of the Hanford RBT. Risks in this bin looked at how the identification of waste form requirements might be impacted by decisions made for the overall Hanford site (such as how much of the overall risk budget should be allocated to secondary waste) and decisions associated with other processes (such as changes and uncertainties associated with design of waste treatment facilities). The main need identified for these risks was a technically defendable method to decide what part of the overall risk budget can and should be attributed to secondary waste.

\subsubsection{Waste Acceptance Criteria}

Risks WAC-1, WAC-2 (REG-1) and WAC-3 (REG-2) were binned into the sub-activity on development of final waste acceptance criteria. In addition, the roadmapping team noted that another risk associated with this work is the ability to adequately identify and describe the required accuracy and relevance of technical information for regulatory decisions. These risks focus on the uncertainties associated with translating performance objectives into discrete acceptance criteria and standards that potential wastes forms can be accurately measured and evaluated against. The need to address these risks was a technically defendable method to convert the regulatory requirement (e.g., a drinking water standard) into acceptance criteria that could be measured on the waste form (e.g., a factional annual contaminant release rate).

Table 3.1. Secondary Waste Treatment and Disposal Needs Summary Tables Legend for Appendix B

\begin{tabular}{lll}
\hline \multicolumn{1}{c}{ Label } & \multicolumn{1}{c}{ Level 2 Roadmap } & \multicolumn{1}{c}{ Risk or Uncertainty Group } \\
\hline RR-x & Regulatory Requirements & Regulatory Requirements \\
WF-PA-x & Regulatory Requirements & Waste Form Development/Performance Assessment \\
RBT-x & Regulatory Requirements & Risk Budget Tool \\
WAC-x & Regulatory Requirements & Waste Acceptance Criteria \\
\hline
\end{tabular}


Improved understanding

suggests standards may

Standards to be

addressed:

- RCRA including LDR

-CWA drinking water

standards

-HLW Definition

-ALARA

\begin{tabular}{|c|}
\hline Legend \\
\hline Level 2 Activity \\
\hline •Identified Risk \\
\hline Primary Outcome \\
\hline Key Feedback Loo \\
\hline
\end{tabular}

be impossible to meet or

may create conflicting

waste form requirements

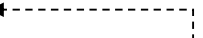 \\ Waste Form Development \\ I Performance \\ Assessment \\ - May not have treatment methods \\ that satisfy standards/criteria \\ - May be too late in developing \\ new waste form if interactions \\ cause problems \\ - May miss waste form that \\ reduces risk \\ - May miss that model predictions \\ are wrong \\ - Unexpected TW/SW EIS result or \\ timing}

Agreed upon list

- Treatment standards may

-Conflicting concentration-

based standards

of requirements

- Lack of agreement on how $\longrightarrow \quad$ \& standards

that must be

addressed

standards

Incidental waste

determination required?

- Other standards may

emerge

- Credible mass balanc

information needed

-TC/SW EIS will not be final

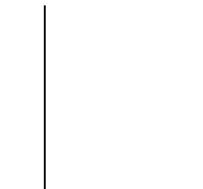

\section{Risk Budget Tool}

- How to decide that part of "overall

risk budget to be attributed to

secondary wastes

to deal with changes,

impacts of other facilities

expected TC/SW EIS result or timing

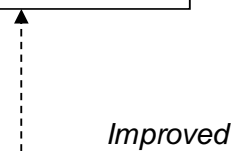

Improved understanding

suggests standards may

be impossible to meet or

may create conflicting

waste form requirements

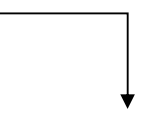

Driving inputs, parameters and assumptions for

WAC

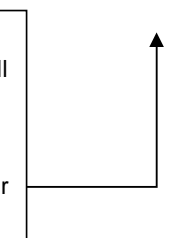

\section{Waste Acceptance}

\section{Criteria}

- Required accuracy and

relevance of technical

information for regulatory

decisions

performance objectives into

performance standards

- Unexpected TC/SW EIS

result or timing

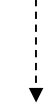

Preliminary Waste

Performance

Requirements

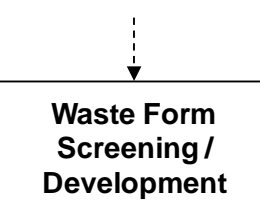

Figure 3.1. Level 2-Regulatory Requirements 


\subsection{Waste Composition}

Several of the risks identified in the secondary waste workshop fell into a broad activity in the roadmap that was given the name of waste composition. As shown in Figure 2.1, this activity starts by defining the inventory of contaminants in the waste tank, determines the changes to the inventory due to retrieval and the primary waste treatment process or processes and ends with a workable range of secondary waste compositions and suitable simulants for testing.

\subsubsection{Waste Composition Sub-Activities}

The waste composition risks fell into several sub-activities that were refined by the roadmapping team to include the following:

- Defining the inventory of chemical and hazardous constituents in the tank wastes

- Determining the impacts of waste retrieval on the tank inventories

- Determining the impacts of WTP waste treatment on the retrieved wastes

- Determining the impacts of alternative waste treatment (e.g., supplemental treatment, early LAW, etc.) on the retrieved wastes

- Generating simulants that represent the chemical and physical properties of the waste and include suitable surrogates for constituents of concern (COCs).

\subsubsection{Waste Composition Sequencing}

The roadmapping team arranged the waste composition sub-activities into a logical sequence that allowed for the potential that WTP or alternate waste treatment flowsheet evolution was likely to refine the secondary waste envelope over time. The resulting Waste Composition Level 2 Roadmap is shown in Figure 3.2. This Level 2 roadmap starts with developing an initial understanding of the inventories in the tanks. This is necessary to determine the types and quantities of hazardous contaminants that might be present in the secondary waste and the likely constituents that will make up the majority of the secondary waste chemistry.

The second step in the waste composition sequence is to determine how retrieval might impact the waste streams that are sent to the primary treatment processes. Retrieval operations through both tank sequencing and non-uniform retrievals within a tank can influence the composition of the waste stream at any given time.

The next steps in the waste composition sequence are to determine how the primary and secondary waste treatment processes will impact the waste stream and the resulting secondary wastes. The WTP will be used to treat all the HLW and at least a large fraction of the LAW. This path in the sequencing is fairly clear and will be based on the WTP flowsheet. The other path in the Level 2 roadmap passes through the alternative waste treatment. This path is less well defined and is dependent on selection of supplemental treatment technology, early operation of WTP's LAW facility before WTP's pretreatment facility comes on line, and decisions on recycling effluents from secondary waste treatment back to WTP or tank farms. The risk discussions generally indicated that tank waste inventory and retrieval uncertainties were likely to be secondary effects compared to potential differences in the flowsheet options and the actual performance of the primary waste treatment processes. 
The last step in the Waste Composition Level 2 Roadmap is the generation of suitable simulants. The risk discussions indicated that it will be necessary to generate simulants based on existing/near-term knowledge of the secondary waste streams to support early waste form development. However, it is likely that continued flowsheet evolution and additional data from primary waste treatment process testing will improve the understanding of the secondary waste stream composition range and may require updates to the range of waste simulants.

\subsubsection{Risks and Needs for Each Waste Composition Sub-Activity}

The product of the first 3 days of the roadmap workshop was a group of risks and a set of needs necessary to address each of those risks. Table 3.2 lists the legend for the numbering of the risks identified by the Waste Composition Group and shown in Appendix C. The fourth day of the workshop binned each of the risks into sets of activities that, after proper sequencing, would become the secondary waste roadmap. The following sections summarize the risks and associated needs that were generated and binned into the Waste Composition sub-activities.

\subsubsection{Define Tank Inventory}

The tank inventory (TI) risks TI-1, TI-2, and TI-3 (WC-3) and risk RBT-2, were binned into this subactivity. These risks generally focused on the uncertainties associated with the tank inventories. These uncertainties include the quantity of known COCs and the possibility of other COCs that are present in the tanks that might impact groundwater standards or other risk pathways. The discussions at the roadmap workshop indicated that the estimated inventories of many of the key COCs in the tanks have been refined over time. However, it was generally thought that uncertainties in the primary waste treatment flowsheets had a much larger impact on the secondary waste composition than possible variations in the tank waste inventories. The main needs to address these risks involved a review of the existing data and a cost benefit analysis of the additional sampling and analyses that would be necessary to reduce the inventory uncertainties.

\subsubsection{Determine Impact of Waste Retrieval}

Waste retrieval (WR) risks WR-1 and WR-2 were binned into this sub-activity. These risks generally focused on the uncertainties associated with the impacts of the retrieval method, the sequence on the feed vectors to the primary treatment process, and the possible impacts to the composition of the secondary waste stream. The discussions at the roadmap workshop indicated that the method of retrieval could concentrate specific COCs in either the earlier or later portions of the tank retrieval and that the sequence of retrieval could also impact the feed vector to the primary treatment process. However, it was generally thought that uncertainties in the primary waste treatment flowsheets had a much larger impact on the secondary waste composition than possible variations introduced by differences in waste retrieval operations. The main needs to address these risks involved a review of the existing data and a cost benefit analysis of the additional sampling and analyses that would be necessary to reduce the uncertainties associated with retrieval.

\subsubsection{Determine Impacts of WTP Waste Treatment}

Waste treatment plant (WTP) risks WTP-1a, WTP-1b, and WTP-2 were binned into this sub-activity. These risks generally focused on the uncertainties related to the WTP flowsheet. The current flowsheet involves several assumptions about the effectiveness of the pretreatment, vitrification, and off-gas treatment processes and significant questions about the quantity of sodium that might need to be treated. 
Many of these assumptions could have a significant impact on the volume of secondary wastes generated and the quantities of COCs that distribute to the secondary wastes. The main needs to address these risks involved a cost-benefit analysis and a review of ongoing WTP studies to determine what additional work might be accomplished to reduce the most significant uncertainties.

\subsubsection{Determine Impacts of Alternate Waste Treatment}

Alternate waste treatment (AWT) risks AWT-1a, AWT-1b, AWT-2a, AWT-2b, and AWT-2c were binned into this sub-activity. These risks generally focused on the uncertainties related to the selection of the alternate waste treatment process and the associated uncertainties in each flowsheet of the selected process. The primary risks involve selection of the supplemental waste treatment technology and uncertainty whether WTP's LAW vitrification facility will begin operations before WTP's pretreatment facility coming on line. The selection of supplemental waste treatment technology and decisions regarding early LAW vitrification have very different impacts on the quantities and compositions of the secondary waste streams. Even after the supplemental waste treatment decision has been made, flowsheet assumptions about the effectiveness of the treatment method exist. Uncertainty also exists regarding the effectiveness of interim pretreatment technologies that would be employed to provide feed to the LAW vitrification facility before the WTP pretreatment facility is operational. Another uncertainty is whether liquid effluents from ETF secondary waste treatment would be recycled to WTP or tank farms. The main needs to address these risks/uncertainties involve early decisions on the supplemental waste treatment technology and/or a secondary waste treatment system that can accommodate a broad range of compositions of potential incoming waste streams.

\subsubsection{Generate Simulants}

Simulant (SIM) risks SIM-1, SIM-2, SIM-3, SIM-4 (WC-2), and SIM-5 (WC-4) were binned into this sub-activity. These risks generally focused on the uncertainties in the compositions of the secondary wastes and how those variations would be addressed with simulants. Uncertainties associated with the applicability of non-radioactive surrogates were also included in the simulant sub-activity. The main needs to address these risks were a set of simulants that addressed the complete range of secondary wastes that are expected from the primary treatment processes (WTP and alternate treatment). The use of nonradioactive surrogates needed a validation plan to verify that the surrogates generated reliable results or were supplemented, where necessary, by radioactive tests with spiked simulants or actual wastes.

Table 3.2. Secondary Waste Treatment and Disposal Needs Summary Table Legend for Appendix C

\begin{tabular}{lll}
\hline Label & \multicolumn{1}{c}{ Level 2 Roadmap } & \multicolumn{1}{c}{ Risk or Uncertainty Group } \\
\hline TI-x & Waste Composition & Define Tank Inventory \\
WR-x & Waste Composition & Determine Impacts of Waste Retrieval \\
WTP-x & Waste Composition & Determine Impacts of WTP Waste Treatment \\
AWT-x & Waste Composition & Determine Impacts of Alternate Waste \\
& & Treatment \\
SIM-x & Waste Composition & Generate Simulants
\end{tabular}



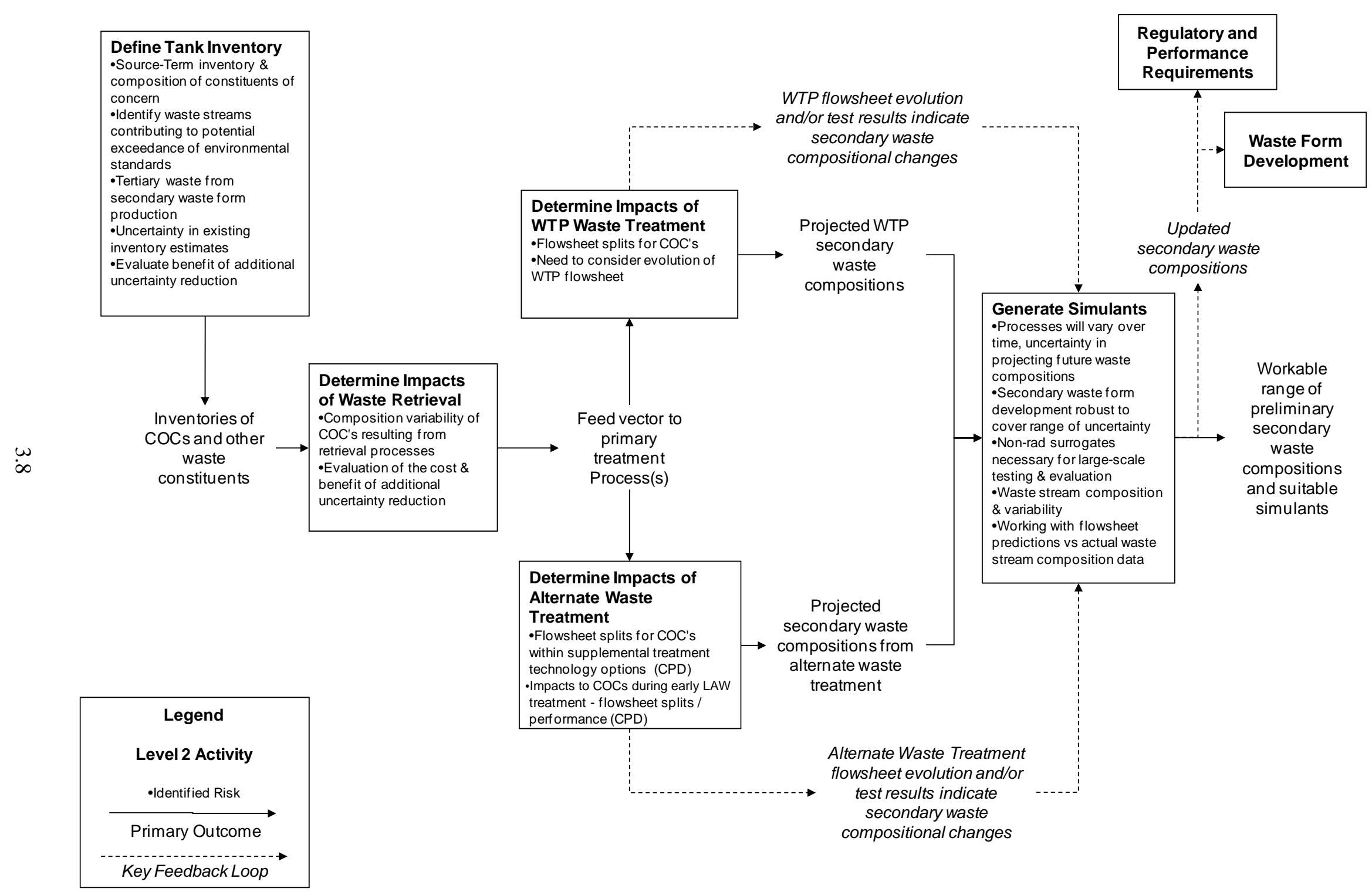

Figure 3.2. Level 2-Waste Composition 


\subsection{Preliminary Waste Form Screening}

Several of the risks identified in the secondary waste workshop fell into a broad activity in the roadmap that was given the name of preliminary waste form screening. As shown in Figure 2.1 (Over arching Roadmap), this activity starts with the best available understanding of the waste performance requirements and the range of possible secondary waste compositions. The preliminary waste form screening portion of the roadmap uses available information and additional test data that can be quickly collected to reduce the possible secondary waste forms to a short list of candidates that have the highest potential to meet the waste performance requirements.

\subsubsection{Waste Form Screening Sub-Activities}

The preliminary waste form screening risks fell into three sub-activities that were refined by the roadmapping team to include the following:

- Identifying a comprehensive list of candidate secondary waste forms and any associated secondary waste pretreatment processes

- Developing test methods to quickly and accurately screen potential waste forms

- Developing and conducting the waste form screening/down-selection process that balances all the relevant criteria.

\subsubsection{Preliminary Waste Form Screening Sequencing}

The roadmapping arranged the preliminary waste form screening sub-activities into a logical sequence that allowed for the potential that the screening activity could be a highly iterative process. The resulting Preliminary Waste Form Screening Level 2 Roadmap is shown in Figure 3.3. This Level 2 roadmap starts with identifying a comprehensive list of candidates. This is an important activity to verify that all the secondary waste forms that might meet the secondary waste performance requirements are considered in the preliminary screening.

Another step in this portion of the roadmap would be to select/develop screening tests that would allow for an effective down-selection of the comprehensive list of candidates. These screening tests need to determine the relative effectiveness of different types of waste forms using short-term tests that have relevance to the release mechanism that is active in the waste from and the anticipated Hanford disposal environment.

The last step in the Preliminary Waste Form Screening Level 2 Roadmap is the waste form screening/down selection. This screening process will take into account the costs and maturity of the different waste forms in addition to the predicted performance. The desired outcome of this screening process is a short list of secondary waste forms that merit further investment. However, this screening process may show that there is not enough useful information from the available screening tests to make a down selection requiring a feedback loop to develop better screening tests. Another possible outcome from the screening/down section process and the overall preliminary waste form screening activity is that the best available performance will not meet performance objectives established for the secondary waste form. This would require a feedback loop to the regulatory and performance activity to look at possible alternatives, such as a reallocation of a greater fraction of the risk budget to the secondary wastes. 


\subsubsection{Risks and Needs for Each Waste Form Screening Sub-Activity}

The product of the first 3 days of the roadmap workshop was a group of risks and a set of needs necessary to address each of those risks. Table 3.3 lists the legend for the numbering of the risks identified by the Waste Form Group and shown in Appendix D. The fourth day of the workshop binned each of the risks into sets of activities that, after proper sequencing, would become the secondary waste roadmap. The following sections summarize the risks and associated needs that were generated and binned into the Preliminary Waste Form Screening sub-activities.

\subsubsection{Identify Comprehensive List of Candidates}

Waste form screening (WFS) risk WFS-6 and waste form development/performance assessment (WF-PA) risks WF-PA-3 and WF-PA-4 were binned into this sub-activity. The roadmapping team added a potential risk that some effective candidates are not included in the starting list. These risks generally focused on the uncertainties associated with making sure that all viable waste forms and potential secondary waste pretreatment options are identified early in the down-selection process so that they can be fairly evaluated. A rigorous process that identifies potential pretreatment options and available waste form is necessary to address these risks.

\subsubsection{Develop Waste Form Screening Tests}

Waste form screening (WFS) risks WFS-1, WFS-2, WFS-3a, WFS-3b, and WFS-7 were binned into this sub-activity. These risks generally focused on the inability to effectively screen the possible waste forms down to a manageable list that merits further investigation. A set of screening tests (i.e., fast and inexpensive) to evaluate the relative performance of the candidate waste forms are needed to address this risk.

\subsubsection{Conduct Waste Form Screening/Down Selection}

Waste form screening (WFS) risks WFS-1, WFS-2, WFS-4, and WFS-5 were binned into this subactivity. These risks generally focused on the difficulties associated with narrowing the potentially large number of options in the absence of verified and consistent information on each option. A process that is capable of taking limited waste form performance data and varying levels of cost and maturity information, and effectively narrowing the list of potential candidates is necessary to address this need. 
Table 3.3. Secondary Waste Treatment and Disposal Needs Summary Table Legend for Appendix D

\begin{tabular}{|c|c|c|}
\hline Label & Level 2 Roadmap & Risk or Uncertainty Group \\
\hline WFS-X & $\begin{array}{l}\text { Preliminary Waste Form } \\
\text { Screening }\end{array}$ & $\begin{array}{l}\text { Identify Comprehensive List of Candidates, } \\
\text { Develop Waste Form Screening Tests, } \\
\text { Conduct Waste Form Screening/Down Selection }\end{array}$ \\
\hline WF-X & Waste Form Development & Develop Initial Understanding \\
\hline TM-X & Waste Form Development & Develop Mechanism Testing \\
\hline WFA-X & Waste Form Development & $\begin{array}{l}\text { Generate Refined Understanding of Waste Form Aging } \\
\text { Release Mechanism }\end{array}$ \\
\hline DI-X & Waste Form Development & Generate Refined Understanding of Disposal Interactions \\
\hline PAM-X & Waste Form Development & PA Modeling \\
\hline PV-x & Validation & Validation \\
\hline PDS-X & Process and Design Support & Process and Design Support \\
\hline DQ-X & Crosscutting & Data Quality \\
\hline REG-X & Regulatory Requirements & Various \\
\hline WC-X & Waste Composition & Various \\
\hline WAC-X & Regulatory & Waste Acceptance Criteria \\
\hline
\end{tabular}


Screening tests do not support a useful
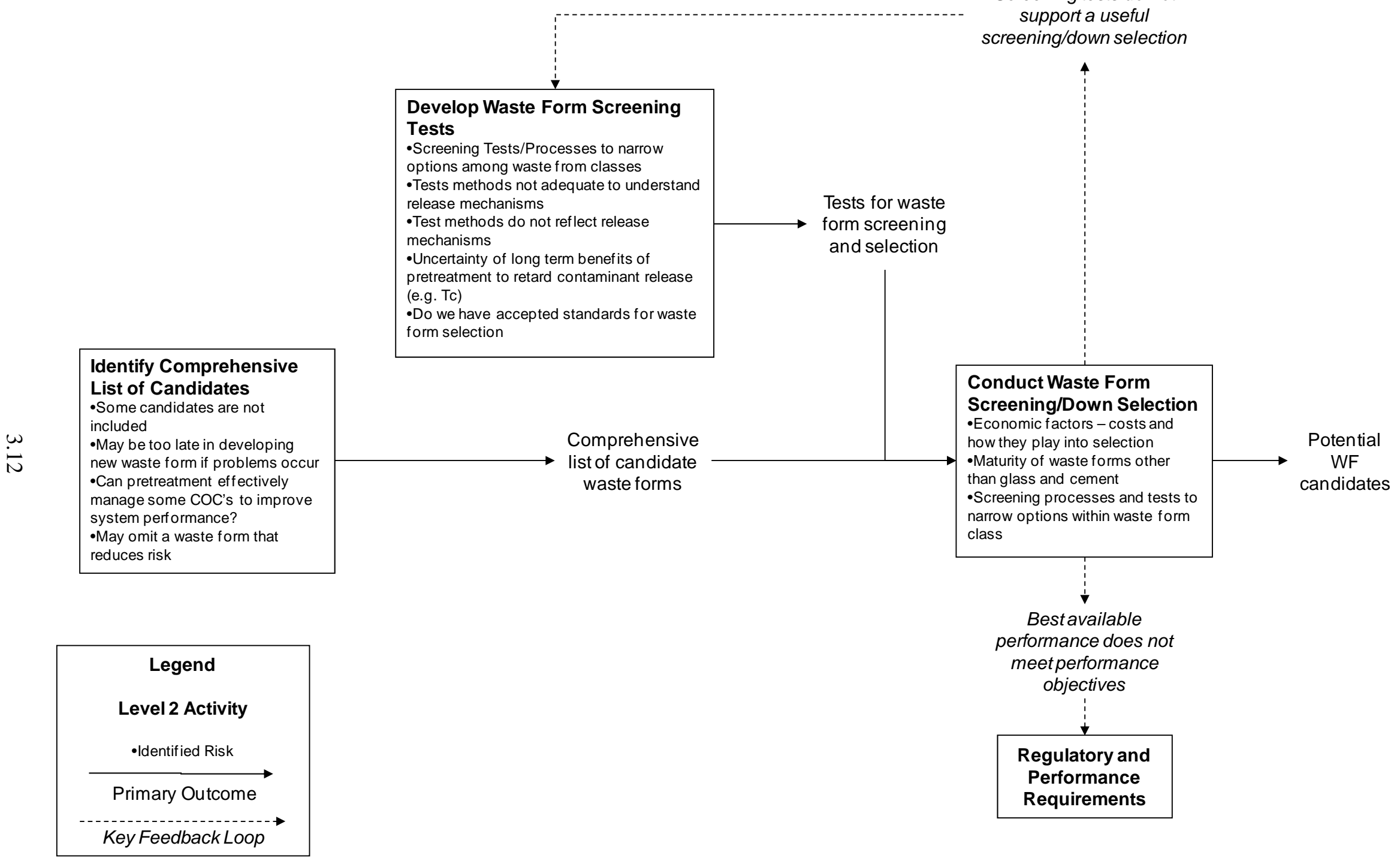

Figure 3.3. Level 2_Preliminary Waste Form Screening 


\subsection{Waste Form Development}

Several of the risks identified in the secondary waste workshop fell into a broad activity in the roadmap that was given the name of waste form development. As shown in Figure 2.1, this activity starts with a group of potential waste form candidates that have passed an initial screening and have potential for supplying the performance to meet requirements for contaminant release rates. The waste form development portion of the roadmap makes an additional investment in one or more candidate waste forms to better understand the characteristics of the waste form that controls contaminant release. This understanding is necessary to generate the main outcome of this activity: a defendable long-term release rate to support a decision for secondary waste disposal.

\subsubsection{Waste Form Development Sub-Activities}

The waste form development risks fell into several sub-activities that were refined by the roadmapping team to include the following:

- Developing an initial understanding of the actual Hanford disposal environment

- Developing test methods to determine the mechanisms that control contaminant release

- Generating a refined understanding of the release mechanisms that allows defendable extrapolation of waste form performance to PA time frames

- Generating a refined understanding of the waste form interactions with the rest of the disposal system

- Conducting the PA modeling necessary to show that the final secondary waste form results in a compliant disposal operation.

\subsubsection{Waste Form Development Sequencing}

The roadmapping team arranged the waste form development sub-activities into a logical sequence that allowed for the potential that the waste form development activity could be a highly iterative process. The resulting Waste Form Development Level 2 Roadmap is shown in Figure 3.4. This Level 2 roadmap starts with developing an initial understanding of the disposal environment. This is necessary to focus efforts to determine the dominant waste form/waste form package release mechanisms in the Hanford environment.

Existing release mechanism test methods available for radioactive waste forms may have limited application for determining release mechanisms for current and novel secondary waste forms, so the next step in the roadmap would be to develop tests that could determine the release mechanisms. These test methods would then generate the data necessary to develop a better understanding of contaminant release from the waste form that will clarify what aging characteristics of the waste form are important. This better understanding of the release mechanism may be sufficient to generate defendable contaminant release rates but is more likely to suggest potential waste form improvements and additional aging/release mechanism tests to support defendable long-term release rates.

The data from mechanism testing will also help support the generation of a refined understanding of the waste form interactions with the rest of the disposal site. The improved understanding of disposal site 
interactions may be sufficient to alleviate concerns about undesirable interactions but might also suggest waste from modifications or additional testing.

The last step in the Waste Form Development Level 2 Roadmap is the comprehensive performance assessment that ties together the understanding of the waste form release and aging mechanisms and all the waste form interactions with the disposal system to determine how the overall system will perform during the period of interest. Although the comprehensive PA is a necessary final step, the PA or portions of the PA will be run several times during the waste form development sub-activity to gauge progress towards establishing defendable/acceptable contaminant release rates. It is anticipated that early PA runs will point out an insufficient understanding of the contaminant releases and/or interactions that may drive additional test development. Another possible outcome from the comprehensive PA and the overall waste form development activity is that best available performance does not meet objectives established for the secondary waste form. This would require a feedback loop to the regulatory and performance activity to look at possible alternatives, such as a reallocation of a greater fraction of the risk budget to the secondary wastes.

\subsubsection{Risks and Needs for Each Waste Form Development Sub-Activity}

The product of the first 3 days of the roadmap workshop was a group of risks and a set of needs necessary to address each of those risks. The fourth day of the workshop binned each of the risks into sets of activities that, after proper sequencing, would become the secondary waste roadmap. The following sections summarize the risks and associated needs that were generated and binned into the Waste Form Development sub-activities.

\subsubsection{Develop Initial Understanding}

Waste form (WF) risks WF-1 through WF-4 were binned into this sub-activity. These risks generally focused on uncertainties related to the disposal environment and assumptions on how that environment might change over time. One of the needs necessary to address these risks focused on defining the baseline disposal conditions (chemical/physical/radiological) that might impact specific waste forms. A second major need focused on defining the right balance of reasonable (necessary and sufficient) release scenarios to evaluate.

\subsubsection{Develop Mechanism Testing}

Testing of the waste form release mechanism (TM) risks TM-1 through TM-4 were binned into this subactivity. These risks generally focused on the ability to establish meaningful short-term/accelerated tests that could predict the long-term performance of secondary waste forms. One need necessary to address these risks was the generation of sample preparation and curing protocols that verified that the tested waste forms had the same mineral composition and key chemical and physical properties as the ultimate full-scale waste form. These protocols were likely to be waste form specific. The second need was to generate an accelerated test that 1) takes into account the full range of proposed disposal conditions, 2) changes the waste form only in ways that are representative of disposal environmental changes, and 3) generates information that allows the generation of defendable, long-term degradation and contaminant release performance.

\subsubsection{Generate Refined Understanding of Release Mechanism}

Waste form aging (WFA) risks WFA-1 through WFA-5 were binned into this sub-activity. These risks generally focused on the lack of understanding associated with secondary waste form aging and 
degradation and the associated impacts on the release mechanism. Other risks were concerned with the impacts of other aspects of the disposal environment (e.g., radiation, microbial effects) on the waste form performance and the possibility of other non-aqueous release pathways. One of the needs necessary to address these risks was an understanding of how the physical properties of the waste changed over time and how this aging might impact contaminant release rates. Another need is to develop an understanding of how the waste form is impacted by other aspects of the disposal environment to determine what factors might play a significant role in contaminant release and what factors can be dismissed as being insignificant. A final need is to determine if non-aqueous release pathways are significant for any of the contaminants present in the final waste form.

\subsubsection{Generate Refined Understanding of Waste/Disposal System Interactions}

Disposal interaction (DI) risks DI-1 through DI-6 were binned into this sub-activity. These risks generally focused on uncertainties related to how the waste form would interact with other parts of the disposal system. Areas of uncertainty included how co-disposed waste forms would interact, how leachate from the waste form would impact the migration of contaminants beneath the disposal facility, how waste form dimensional changes (expansion/subsidence) might impact surface barriers, how the disposal environment might change the chemical from of contaminants, and how changes to the disposal surface environment, including intruder scenarios, might impact waste form performance.

\subsubsection{PA Modeling}

Performance assessment modeling (PAM) risks PAM-1 through PAM-6 were binned into this subactivity. These risks generally focused on the difficulties associated with generating a technically defensible contaminant release model that includes all credible release scenarios and adequately bounds all associated uncertainties. The model will need to account for waste form aging; chemical/physical/radiological properties that impact COC release mechanisms and performance; and interactions with the disposal environment over time. Needs to address these risks include an understanding of the important factors that impact COC release mechanisms and waste form aging; test methods to help determine the important factors and characterize the expected contaminant release rates over a broad range of disposal conditions; and a technically defensible model of the waste form release in response to the environmental conditions in the context of a PA. 

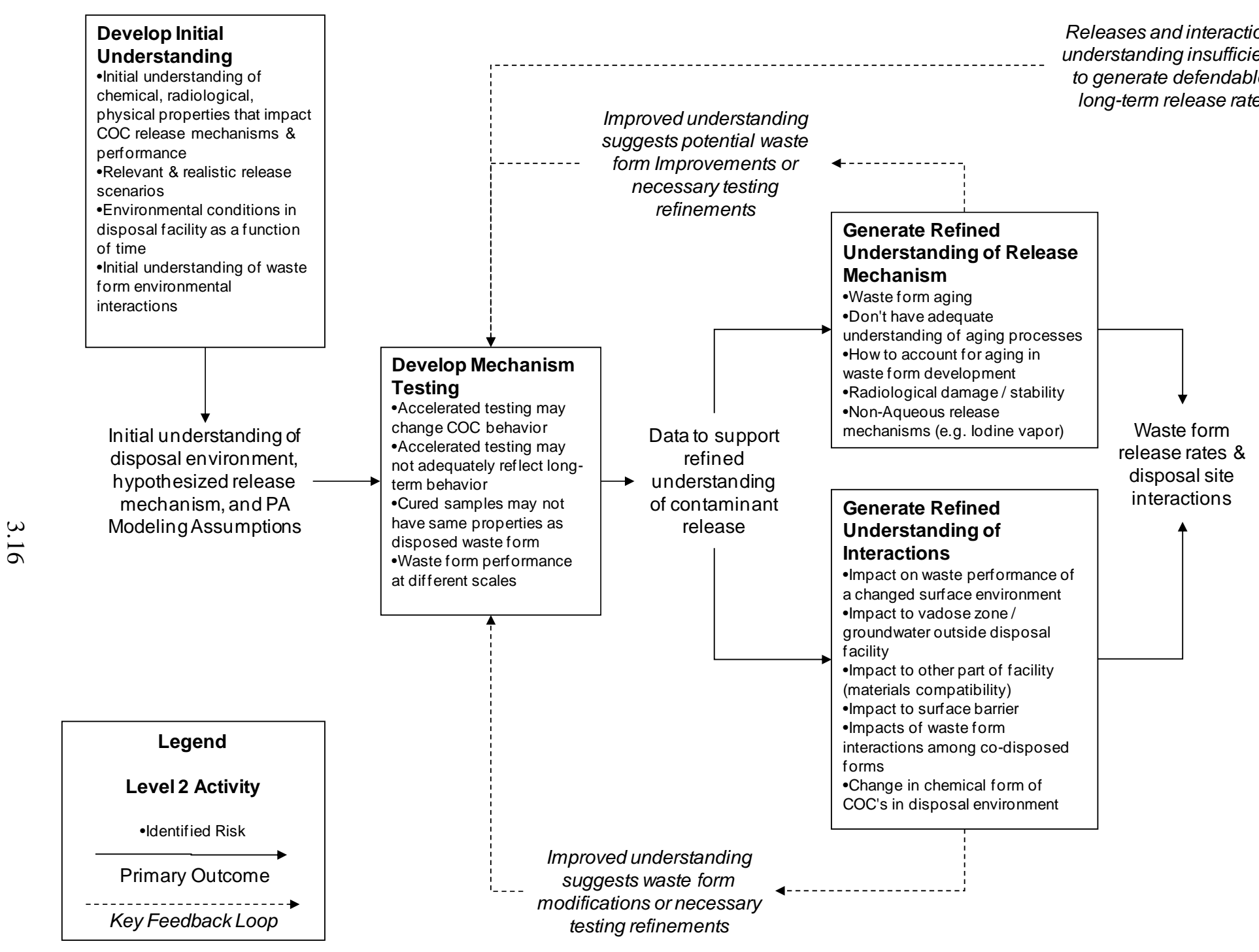


\subsection{Validation}

Several of the risks identified in the secondary waste workshop fell into a validation activity. As shown in Figure 2.1, this activity starts with the selected waste forms for a defined group of formulations and confirms that the waste forms meets regulatory requirements for waste disposal.

\subsubsection{Validation Sub-Activities}

The validation portion of the roadmap is highly dependent on the final waste form that is selected. As the number of possible waste forms is narrowed down, the validation activity should be looked at more closely to determine if it should be broken into additional sub-activities. This workshop left the validation as a single activity.

\subsubsection{Validation Sequencing}

By the time the roadmap has progressed to the validation stage, there should be a high probability that the secondary waste form will perform as designed. However, the roadmapping team allowed for the potential that the validation activity could find a concern with the waste form. This is shown in the Validation Level 2 Roadmap (see Figure 3.5) as a feedback loop that leads to additional waste form development.

\subsubsection{Risks and Needs for Validation}

Performance Validation (PV) risks PV-1 through PV-4 were binned into the validation activity. These risks generally focused on uncertainties related to the actual performance of the waste form in the actual disposal environment. Uncertainties related to the role of analogues were also binned into this activity. The needs necessary to address these risks included demonstrating waste form performance in simulated disposal environments, monitoring disposal system performance, and assessing natural and man-made analogues to address long-term performance of waste forms. 


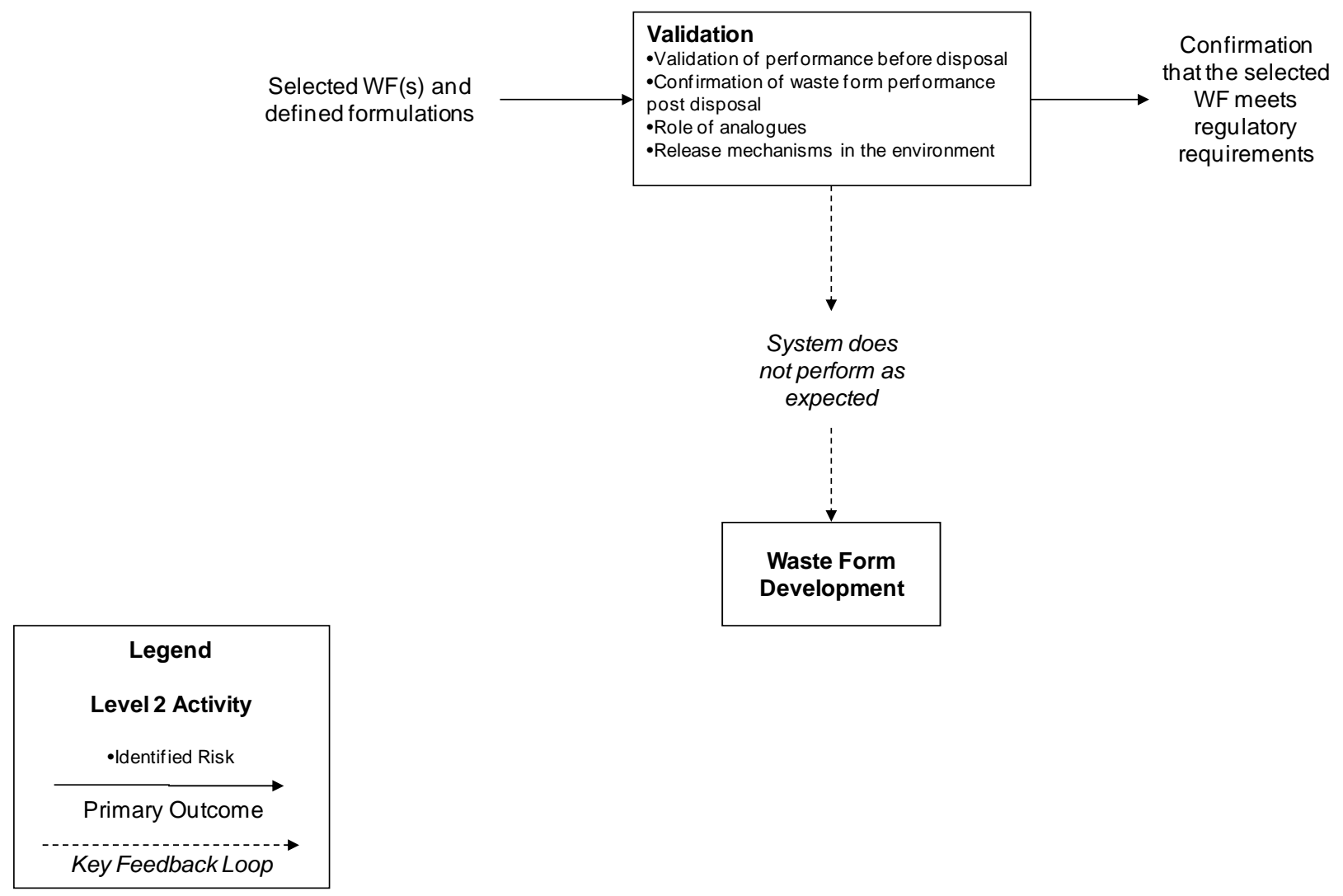

Figure 3.5. Level 2-Validation

\subsection{Process and Design Support}

Several of the risks identified in the secondary waste workshop fell into a process design support activity. As shown in Figure 2.1, this activity starts with input to the critical decision (CD) process for secondary waste treatment facilities and finishes by supplying reliable process flowsheet input to support a robust facility design. Critical Decisions are part of DOE's management system for the acquisition of capital assets (DOE 2003)

\subsubsection{Process and Design Support Sub-Activities}

The design support portion of the roadmap was mostly outside of the stated scope of the workshop. However, it was clear that the ability to produce the desired waste form in a repeatable fashion, at the required scale, and at the required throughput needed to be included at a high level in the roadmap. This workshop left design support as a single high-level activity.

\subsubsection{Design Support Sequencing}

By the time the roadmap has progressed to the stage where plant designs are ready to be finalized, there should be a high probability that the secondary waste can be produced at the required size and at the required throughput. However, the roadmapping team allowed for the potential that the design support activity might identify an unanticipated constraint that would require additional waste form development. This is shown in the Design Support Level 2 Roadmap (see Figure 3.6) as a feedback loop that leads to 
additional waste form development. There is also the possibility of a tertiary waste stream that needs to be incorporated into the waste composition activity.

\subsubsection{Risks and Needs for Process and Design Support}

Process and Design Support (PDS) risks PDS-1 through PDS-5 were binned into the design support activity. These risks generally focused on uncertainties related to the quality assurance/quality control (QA/QC) necessary to verify acceptable waste form production; the physical form of the treated waste and waste form package; and the size and quantity of scale-up testing necessary to verify that the process is ready to implement production. One of the needs necessary to address these risks included the development of an acceptable process window that defined limits for waste components, material additions, and process parameters. Other needs included a definition of the desired final waste form package and pilot-scale fabrication testing to demonstrate the ability to scale up the process.

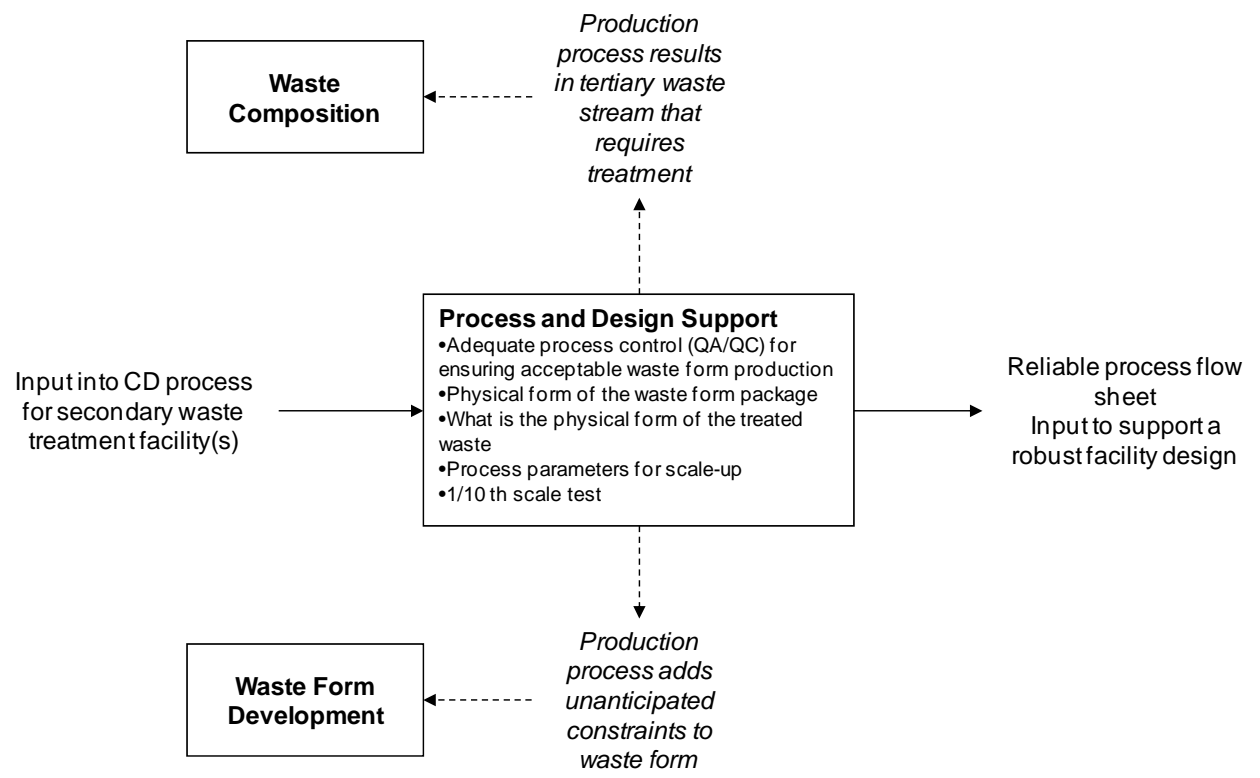

Figure 3.6. Level 2-Process and Design Support 


\subsection{Program Need Elements to Address Secondary Waste Risks and Uncertainties}

The work necessary to address the programmatic, regulatory, and technical risks and uncertainties identified through the Secondary Waste Roadmap Workshop, as summarized in the previous section, can be assembled into several program needs elements.

Programmatic/Regulatory needs include:

- Select and deploy Hanford tank waste supplemental treatment technology

- Provide treatment capability for secondary waste streams from tank waste treatment

- Develop consensus on secondary waste form acceptance.

Technology needs include:

- Define secondary waste composition ranges and uncertainties

- Identify and develop waste forms for secondary waste immobilization and disposal

- Develop test methods to characterize secondary waste form performance.

The latter two technology needs are anticipated at least in part in DOE-EM planning documents, including the Engineering and Technology Roadmap (DOE-EM 2008a) and the Office of Engineering and Technology's Integrated Multi-Year Program Plan (FY2008-FY 2010) (DOE-EM 2008b). The Enhanced Stabilization Technologies strategic initiative identified an activity to develop supplemental treatment processes that consider secondary waste from tank farm and vitrification plant operations at SRS, Hanford, Idaho National Laboratory (INL), and Oak Ridge National Laboratory (ORNL). Similarly, a cross-cutting strategic initiative is identified for Enhanced Long-Term Performance Evaluation and Monitoring to increase the understanding of long-term waste form performance.

Each of the programmatic/regulatory and technology needs is described in the following sections. These need statements provide additional perspective for expanding the scope to address the secondary waste treatment risks and uncertainties for existing EM engineering and technology strategic initiatives.

\subsection{Select and Deploy Hanford Tank Waste Supplemental Treatment Technology}

DOE's Office of River Protection is considering a number of options to provide additional capacity for immobilizing Hanford's low-activity tank wastes. Supplemental treatment options being considered include building a second LAW vitrification facility and bulk vitrification. Flowsheet analyses of these options show that each has some impact on the quantities of ${ }^{99} \mathrm{Tc}$ and ${ }^{129} \mathrm{I}$ in the secondary wastes to be disposed of in the IDF. In addition, DOE is considering early operation of the LAW vitrification facility before the pretreatment facility comes on line. Operation of the WTP LAW facility before the pretreatment facility is available to receive recycle streams would result in an increase in the amount of

${ }^{99} \mathrm{Tc}$ in the liquid wastes to be treated in ETF from $0.3 \%$ to $11 \%$ of the starting tank inventory. ORP's tank farm contractor has an ongoing program to provide DOE with the information necessary to resolve the supplemental treatment question. It is outside the scope of the secondary waste roadmapping exercise 
to examine this work. It is identified here to emphasize the importance of the decision on the secondary waste treatment.

\subsection{Provide Treatment Capability for Secondary Waste Streams from Tank Waste Treatment}

Secondary waste streams from treatment of tank waste will be treated and immobilized in ETF with a proposed new solidification treatment unit. There is a lengthy design, procurement, construction, and startup process for this new capability. The new or upgraded facility will need to be operational at least by the time WTP is scheduled to begin hot commissioning-September 2017. If DOE decides to proceed with early operation of WTP's LAW facility, the need date for the secondary waste treatment facility or upgraded ETF could be as early as 2014. Decisions on design configuration of the new or upgraded facility are needed much earlier. Those decisions are dependent on results of waste-form screening, at a minimum. Schedules are needed that tie activities in this road map to key milestones and timelines for the secondary waste treatment facility project timelines.

\subsection{Develop Consensus on Secondary Waste Form Acceptance}

Secondary wastes will be treated and disposed of within a regulatory framework that addresses federal and state requirements, including DOE disposal requirements for low-level wastes, federal and state requirements for land disposal restrictions, federal drinking water standards, and applicable Hanford dangerous waste permit conditions for WTP, ETF and IDF. DOE and the Washington State Department of Ecology (Ecology) are working together within these regulatory requirements to provide the waste acceptance for a compliant waste form for the treatment and disposal of the secondary wastes. In developing a consistent and comprehensive set of requirements, it may be necessary to address uncertainties, including 1) the impact of waste codes on treatment standards that will be applied to the wastes, 2) the potential that there are not treatment standards or methods that satisfy the codes, 3) the impacts of conflicting standards, and 4) the applicability of other standards, such as CERCLA.

The secondary waste form will need to meet performance requirements with respect to controlling the release of contaminants to the environment. These requirements will be established through the conduct of risk and performance assessments and the application of the RBT to determine the amount of the overall risk to be attributed to the secondary wastes. In developing the performance requirements, it may be necessary to address technical imperatives that may limit the ability of a secondary waste form to meet all regulatory requirements and on the potential for regulatory requirements to constrain waste form evaluation and development in ways that result in sub-optimal results.

The ultimate outcome of this work will be set of consensus waste acceptance criteria that the secondary waste forms must meet for disposal in IDF. The waste acceptance criteria will address prescriptive regulatory requirements and performance requirements that consider the totality of wastes to be disposed of in IDF.

\subsection{Define Secondary Waste Composition Ranges and Uncertainties}

Chemical composition information, including major constituents and low-concentration COCs in secondary wastes, is needed to support process and waste form development and design and to assess the impact of disposal of the secondary wastes. Before actual WTP operations, the chemical composition of 
secondary wastes from WTP must be established based on 1) estimates of the compositions of the tank wastes, 2) estimates of the partitioning of the chemicals through tank retrieval, 3) WTP pretreatment, vitrification, and effluent treatment processes; and 4) flowsheet models of those processes. Work to date indicates that the largest uncertainties in estimating the composition of COCs, including ${ }^{129} \mathrm{I},{ }^{99} \mathrm{Tc},{ }^{238} \mathrm{U}$, mercury, chromium, nitrate, and total uranium, are due to uncertainties in the tank inventory of these components and uncertainties associated with options being considered to accelerate the WTP mission completion date. These options include early operation of the WTP LAW facility, enhancing the capacity of the LAW melter through melter and waste-loading improvements, and adding additional treatment capacity via alternate treatment technologies and/or adding a secondary LAW vitrification facility. For example, estimates for one scenario for early operation of the LAW vitrification facility indicate that the lifecycle impact increases the amount of ${ }^{99} \mathrm{Tc}$ in the liquid wastes treated in ETF from $0.3 \%$ to $11 \%$ of the starting technetium tank inventory.

Work is needed to evaluate the uncertainties associated with the tank inventories and treatment process options and parameters to understand the ranges and uncertainties in the estimated compositions of the secondary wastes to be disposed of in IDF. The results of the evaluation will provide a determination of if and where additional sampling and analyses, testing with real waste or simulants, and/or process (kinetic) and thermodynamic modeling are needed to reduce the uncertainties to acceptable levels to support process and flowsheet decisions and to support disposal system risk assessments. The sampling and analyses, testing, and modeling would be performed where indicated.

Based on the estimated range of secondary waste compositions, chemical and physical simulants must be developed to support secondary waste form development. The simulants must be robust enough to cover the range of uncertainties, potential treatment process configurations, and operating scenarios. The simulants must anticipate testing at various scales and include radioactive and non-radioactive surrogates for ${ }^{129} \mathrm{I}$ and ${ }^{99} \mathrm{Tc}$ in particular. As the waste treatment flowsheets mature, the simulants may require updates should the waste stream compositions change. The use of simulants and non-radioactive surrogates requires validation with spiked simulants and/or actual wastes to add confidence in the results with non-radioactive simulants.

The outcomes of this work will directly support decisions on waste treatment flowsheet options, secondary waste form development, secondary waste treatment facility decisions, and disposal system risk assessments.

\subsection{Identify and Develop Waste Forms for Secondary Waste Immobilization and Disposal}

One or more waste forms are needed to immobilize and dispose of secondary wastes from the treatment of Hanford tank wastes. The waste form(s) will be expected to 1) have properties that do not compromise the design and performance of the IDF and 2) contain contaminants in the secondary wastes to meet environmental standards. In particular, the waste form(s) will need to be effective in controlling the release of ${ }^{99} \mathrm{Tc}$ and ${ }^{129} \mathrm{I}$, which are projected to be the largest contributors to the long-term impacts of the secondary waste disposal. Development of the waste form will include defining the processes for preparing the waste form, packaging the waste form, and transporting the packaged waste form to the IDF. Because of the volatility of technetium and iodine in thermal processes, it is expected that the immobilization process will be at relatively low temperatures to avoid the generation of tertiary wastes 
requiring still further treatment and disposal. A technology maturation plan (DOE-EM 2008c) will be used to guide the secondary waste form(s) development.

A multi-step process will be used to develop the secondary waste form. The first step is to identify candidate waste forms and screen those waste forms, leading to the selection of one or more candidates for further development. The initial search for candidates needs to be comprehensive and needs to consider flowsheet options that would effectively manage the COCs before reaching the secondary waste treatment facility. Screening tests for the waste forms need to recognize that current standardized tests for glass and cement waste forms may not be appropriate for the candidate waste forms and may not reveal the true waste form performance. As such, the screening testing and indeed the entire waste form development process needs to be conducted in parallel and with full communication with the test methoddevelopment activity described below. Based on the results of the screening tests and considerations of economic and regulatory factors, one or more candidate waste forms will be selected for further development.

Waste form development will focus on improving the performance of the selected secondary waste forms. This will include improvements to the waste loading, processing rates, tertiary waste minimization, and contaminant release rates. This may include testing of sequestering agents to further reduce the mobility of key contaminants. Any such sequestering agents will need to be tested to determine long-term effectiveness of that sequestering agent in the disposal system. The immobilization process itself will need to be tested to develop a reliable process flowsheet and to provide information to support a robust facility design. This will require some process testing in at least tenth scale and will need to include the waste form packaging.

An important aspect of waste form development is examining the long-term performance of the waste form to support risk and performance assessments. This will require focused testing to understand the chemical, radiological, and physical properties that impact the contaminant release mechanisms and waste form performance. The testing will need to reveal the release rates of the major waste-form components as well as for the key contaminants over time, how those release rates and the waste form performance change as the waste form ages in the disposal facility, and how the waste form and its contaminants interact with the disposal environment, including any co-disposed wastes. Ultimately, models of the waste form performance and contaminant release are needed for the risk and performance assessment calculations. It is expected that the waste form development and risk and performance assessment activities will be conducted in an iterative process in which the initial understanding of the waste form behavior will be examined via risk assessment analyses. Also, the waste form performance and the understanding of that performance will be improved as necessary until the projected impacts and uncertainties in those projected impacts are at acceptable levels. The waste form performance will be validated with a demonstration in a disposal-system environment and should include the appropriate scale, accelerated testing, and disposal conditions. An assessment of natural and man-made analogues and other disposed waste may be used to reduce the uncertainty in waste form selection and estimated performance of the waste form. ASTM International has provided guidance (C-1174) for predicting the long-term behavior of waste forms for radioactive waste disposal that outlines this approach in greater detail.

The ultimate outcome of the waste form development is a robust waste form that meets waste-acceptance criteria for the disposal facility, is cost effective from a materials and facility perspective, and is 
protective of workers, the public, and the environment. The development effort will also provide the models of long-term waste form performance and contaminant release and supporting data for the risk assessment and performance assessments to estimate the impacts of the secondary waste disposal.

\subsection{Develop Test Methods for Secondary Waste Form Characterization}

Waste forms for treating and immobilizing secondary wastes will be required to meet performance requirements to protect workers, the public, and the environment. Typically, these requirements address properties of the waste form such that the waste form does not compromise the design and performance of the disposal system and that the contaminants are adequately contained such that environmental standards are not broached. These requirements typically include performance standards with respect to chemical durability and release rates of the contaminants. For glass waste forms developed for high-level and lowlevel radioactive wastes, test methods such as the product consistency test (ASTM C 1285) and the vapor hydration test have been developed to characterize glass waste forms. The ANS/ANSI 16.1 leachability index test and ASTM Accelerated Leach Test (ALT) (ASTM C 1308) are frequently used for cementitious waste forms. Recent testing of low-temperature waste forms for secondary waste immobilization indicates that these test methods may not be applicable to other classes of waste forms.

A test method development program is needed to provide the tools for evaluating waste form performance. Initially, test methods are needed to support the selection of a waste form(s) from a number of candidates for the immobilization of secondary wastes. As the selected waste form is developed, new test methods may be needed to aid in showing improvements in the waste form and to provide an understanding of the release rates and mechanisms to support risk and performance assessments. These risk and performance assessments also require understanding of how the waste form performance may change over time, so test methods are needed to address waste form aging.

Screening tests are needed to objectively compare the candidates during waste form evaluation and selection when a number of waste form classes are being considered for secondary waste immobilization. At this early stage, there will be an absence of verified and consistent information on the waste form release mechanisms.

Once a waste form(s) is selected, testing will continue as the waste form is further developed to improve performance, increase waste loading, optimize processing rates, and demonstrate production at some scale. Short-term screening tests will be needed to aid the development decisions. At this stage, the test methods need to discern improvements in the waste form that will translate to improvements in the waste form in the disposal environment. As such, the screening test methods will need to reflect some understanding of the release mechanisms and long-term performance. The test methods may be specific to a specific class of waste forms. Therefore, if multiple classes of waste forms are being developed, several different test methods may be required.

At this point, it may be appropriate to consider the screening test for a consensus standard, perhaps for use as a component of the secondary waste-acceptance criteria. This will require intra- and inter-laboratory testing, technical reviews, and documentation.

Finally, test methods will be needed to provide the longer term waste form performance information needed for disposal system risk and performance assessments. This will require test methods to provide 
an understanding of the release mechanisms of the waste form in the disposal environment. The test methods will need to provide information on waste form aging over the longer disposal periods.

Accelerated testing may be considered but must not change contaminant release behavior/mechanism and will require validation in the short term and disposal system monitoring over the longer term. Testing of natural and manmade analogues will support the test method validation. The test methods may provide specific waste form properties used in models of waste form performance based on a more fundamental understanding of the contaminant release mechanisms. Scenario-specific tests may be required for certain disposal system and environmental conditions.

The outcome of this work is a suite of tests for determining waste form performance. The screening tests will provide a means of objectively comparing waste form candidates such that the most promising candidates move forward for further development; however, equally promising but less mature candidates are not eliminated from consideration. The test methods will also provide the necessary information on contaminant release mechanisms and long-term performance in the disposal environment to provide the technical basis for risk and performance assessments of the waste form in the disposal site. Ultimately, the test methods will provide confidence in the path selected for treating, immobilizing, and disposing of the secondary wastes. 


\subsection{References}

American National Standards Institute/American Nuclear Society (ANSI/ANS). 1986. American National Standard Measurement of the Leachability of Solidified Low Level Radioactive Waste by Short Term Procedure. ANSI/ANS 16.1, Washington D.C.

ASTM International. 2007. Standard Practice for Prediction of the Long-Term Behavior of Materials, Including Waste Forms, Used in Engineered Barrier Systems (EBS) for Geological Disposal of HighLevel Radioactive Waste. ASTM C-1174, West Conshohocken, PA

ASTM International. 2008. Standard Test Methods for Determining Chemical Durability of Nuclear, Hazardous, and Mixed Waste Glasses: The Product Consistency Test (PCT). ASTM C-1285, West Conshohocken, PA.

ASTM International. 2008. Standard Test Method for Accelerated Leach Test for Diffusive Releases from Solidified Waste and a Computer Program to Model Diffusive Fractional Leaching from Cylindrical Waste Forms. ASTM C-1308, West Conshohocken, PA.

Crawford TW. 2008. Secondary Waste Strategy for Early Low Activity Waste Treatment. RPP-RPT37924 Rev. 0, CH2MHill, Richland, Washington.

U.S. Department of Energy. 1999. Radioactive Waste Management Manual, DOE M 435.1-1, July 1999, Washington D.C.

U.S. Department of Energy. 2003. Project Management for the Acquisition of Capital Assets, DOE M 413.3-1, March 2003, Washington D.C.

U.S. Department of Energy, Office of Environmental Management (DOE-EM). 2000. Applying Science and Technology Roadmapping in Environmental Management, Draft, Washington, D.C.

U.S. Department of Energy, Office of Environmental Management (DOE-EM). 2008a. Engineering and Technology Roadmap, Reducing Technical Risk and Uncertainty in the EM Program, March 2008, Washington D.C.

U.S. Department of Energy, Office of Environmental Management (DOE-EM). 2008b. Integrated MultiYear Program Plan (FY 2008 - FY 2010), March 2008, Washington D.C.

U.S. Department of Energy, Office of Environmental Management (DOE-EM). 2008c. Technology Readiness Assessment (TRA)/Technology Maturation Plan (TMP) Process Guide, March 2008, Washington D.C. 


\section{Appendix A}

\section{Secondary Waste Roadmap Workshop Agenda}




\title{
Appendix A \\ Secondary Waste Roadmap Workshop Agenda
}

\author{
Secondary Waste Roadmap Meeting \\ July 21-23, 2008 \\ Agenda
}

\section{Location:}

The Signature Center

451 Hills Street

Richland, WA

Monday -- July 21, 2008

8:00 Welcome and Perspective (30 minutes)

Ben Harp, Ed Fredenburg, and Moses Jaraysi will welcome participants and offer their perspectives on the goal and objectives for the meeting

8:30 Meeting Format and Guidelines (10 minutes)

Elizabeth McManus will review the meeting format and proposed ground rules.

8:40 Background Information (20 minutes)

Jim Honeyman will discuss the tank inventory and WTP flowsheet, including:

- Options (early LAW, supplemental treatment, others)

- WTP and Supp. Treat flowsheet and Tc, I, other contaminant paths

- Secondary waste sources, compositions, inventories (liquid and solid)

- Secondary waste treatment and disposal paths (liquids and solids)

9:00 Background Information - Continued (30 minutes)

Kristi Lueck will discuss ETF liquid effluent treatment options and Joe Westsik will discuss secondary waste immobilization options including low-temperature immobilization study and steam reforming.

9:30 Background Information - Continued (20 minutes)

Moses Jaraysi and Fred Mann will discuss IDF risk assessment including key contributors to environmental and health risks and treatment standards, permit conditions, and DOE orders.

10:00 Break (15 minutes)

10:15 Waste Composition (1 hour 45 minutes)

Jim Honeyman and Gary Smith will lead a discussion of waste composition issues including: 
- Tank inventory

- LAW treatment options

- Tc and I path through WTP and Supplemental Treatment flowsheets

Waste Composition (3 hours) Glenn Walkley Conference Room at Energy Northwest Building Jim Honeyman and Gary Smith will lead a discussion of waste composition issues including:

- Tc and I path through WTP and Supplemental Treatment flowsheets (continued)

- $\quad$ Tc and I surrogates

- Secondary waste simulants

The group will take a 10 minute break during this time
Regulatory Drivers (3 hours) Signature Center Conference Room Moses Jaraysi will lead the group in a discussion of

- Land disposal restrictions \& drinking water standards

- WTP and ETF Permit Conditions and DOE Orders

- Waste form performance

- Waste form characteristics

The group will take a 10 minute break during this time

4:00 Day 1 Summaries (30 minutes)

Each group will give a 15 minute summary of their progress.

4:30 Adjourn for the Day

The Advisory Panel will meet for dinner at the end of the day. 
Tuesday -- July 22, 2008

Signature Center Conference Room

\section{8:00}

Waste Form -- Introductions, Approach, Roadmap Topics (10 minutes)

8:10 Waste Form - Additional Background Information

Larry Bagaasen and Fred Mann will provide additional background information regarding waste forms and waste form performance.

9:00 Waste Form (3 Hours)

Building on the outcomes from the waste composition and regulatory drivers discussions of Day 1, Larry Bagaasen will lead the group in a discussion of waste form issues including:

- Waste form selection

- Contaminant release mechanisms

- Testing methodologies to determine waste form performance

- Demonstration, verification, and monitoring to validate waste form performance

- Waste form component interactions with disposal system and vadose zone

- Data and modeling requirements for assessing long-term performance

The group will take a 15 minute break during this time

12:00 Lunch (60 minutes)

1:00 Waste Form (3 Hours)

Continue discussion of waste form issues including:

- Waste form selection

- Contaminant release mechanisms

- Testing methodologies to determine waste form performance

- Demonstration, verification, and monitoring to validate waste form performance

- Waste form component interactions with disposal system and vadose zone

- Date and modeling requirements for assessing long-term performance

The group will take a 15 minute break during this time

4:15 Day 2 Summary (15 minutes)

The waste form group will give a 15 minute summary of their progress.

4:30 Adjourn for the Day

The Advisory Panel will meet for dinner at the end of the day. 
Wednesday, July 23, 2008

Signature Center Conference Room

8:00

Waste Form (4 Hours)

Continue discussion of waste form issues including:

- Waste form selection

- Contaminant release mechanisms

- Testing methodologies to determine waste form performance

- Demonstration, verification, and monitoring to validate waste form performance

- Waste form component interactions with disposal system and vadose zone

- Date and modeling requirements for assessing long-term performance

The group will take a 15 minute break during this time

12:00 Lunch (60 minutes)

1:00 Waste Form (3 Hours)

Continue discussion of waste form issues including:

- Waste form selection

- Contaminant release mechanisms

- Testing methodologies to determine waste form performance

- Demonstration, verification, and monitoring to validate waste form performance

- Waste form component interactions with disposal system and vadose zone

- Date and modeling requirements for assessing long-term performance

The group will take a 15 minute break during this time

4:00 Day 2 Summary (15 minutes)

The waste form group will give a 15 minute summary of their progress.

4:15 Meeting Closing and Next Steps (15 minutes)

4:30 Adjourn

The Advisory committee will meet from 8:00 to 4:30 on Thursday, July 24, 2008 and 8:00 to 11:30 on Friday, July 25 to synthesize the results of the meeting into the roadmap. 


\section{Appendix B}

Secondary Waste Treatment and Disposal Needs SummaryRegulatory Drivers 


\section{Appendix B}

\section{Secondary Waste Treatment and Disposal Needs Summary—Regulatory Drivers}

\begin{tabular}{|c|c|c|c|c|c|c|}
\hline Label & Group & Element & Risk or Uncertainty & Need Description & $\begin{array}{c}\text { Key Inputs/ } \\
\text { Predecessors }\end{array}$ & Outcomes/ Successors \\
\hline RR-1 & $\begin{array}{l}\text { Regulatory } \\
\text { Drivers }\end{array}$ & Waste codes & $\begin{array}{l}\text { Impact of waste codes } \\
\text { on treatment standards } \\
\text { that will be applied to } \\
\text { Secondary wastes } \\
\text { (listed [known], } \\
\text { characteristic [new } \\
\text { point of generation } \\
\text { (POG)], State criteria } \\
\text { [new POG]) }\end{array}$ & $\begin{array}{l}\text { Need to agree the waste codes that will } \\
\text { be designated. }\end{array}$ & $\begin{array}{l}\text { Acceptable process } \\
\text { knowledge (i.e., } \\
\text { contaminant concentration } \\
\text { and generating source) per } \\
\text { waste acceptance criteria } \\
\text { (WAC) }\end{array}$ & $\begin{array}{l}\text { Establish regulatory basis } \\
\text { for demonstrating } \\
\text { compliance with land } \\
\text { disposal restriction (LDR) } \\
\text { treatment standards }\end{array}$ \\
\hline RR-2 & $\begin{array}{l}\text { Regulatory } \\
\text { Drivers }\end{array}$ & $\begin{array}{l}\text { Treatment standards } \\
\text { or methods }\end{array}$ & $\begin{array}{l}\text { May not know if there } \\
\text { are treatment } \\
\text { standards/ methods } \\
\text { that satisfy codes... }\end{array}$ & $\begin{array}{l}\text { The WTP Permit Condition } \\
\text { III.10.C.2.n.ii } \\
\text { Need to identify what [LDR] treatment } \\
\text { standards or methods go with the waste } \\
\text { codes }\end{array}$ & $\begin{array}{l}\text { Expected performance, cost, } \\
\text { and maturity (TRA) } \\
\\
\text { Best available WAC and } \\
\text { baseline composition info } \\
\text { Extent of stakeholder/ } \\
\text { regulator acceptance } \\
\text { Objective decision criteria }\end{array}$ & $\begin{array}{l}\text { Shortened list of candidate } \\
\text { waste forms }\end{array}$ \\
\hline RR-3 & $\begin{array}{l}\text { Regulatory } \\
\text { Drivers }\end{array}$ & $\begin{array}{l}\text { Application of } \\
\text { Atomic Energy } \\
\text { Agency/Resource } \\
\text { Conservation and } \\
\text { Recovery Act } \\
\text { (AEA/RCRA) }\end{array}$ & $\begin{array}{l}\text { Impacts from } \\
\text { conflicting standards }\end{array}$ & $\begin{array}{l}\text { Need to determine path forward if State } \\
\text { and Federal disagree [...] standards } \\
\\
\text { DOE needs to apply AEA and Ecology } \\
\text { needs to apply Hazardous Waste } \\
\text { Management Act and reach agreement } \\
\text { on treatment and disposal. }\end{array}$ & Need input from DOE & Need input from DOE \\
\hline RR-4 & $\begin{array}{l}\text { Regulatory } \\
\text { Drivers }\end{array}$ & $\begin{array}{l}\text { Concentration Limit } \\
\text { Conversion }\end{array}$ & $\begin{array}{l}\text { Conflicting } \\
\text { concentration } \\
\text { standards }\end{array}$ & $\begin{array}{l}\text { Need to determine how to } \\
\text { concentration limit in groundwater } \\
\text { (GW) (State method vs. NRC/DOE } \\
\text { method) }\end{array}$ & & \\
\hline RR-5 & $\begin{array}{l}\text { Parking Lot } \\
\text { List }\end{array}$ & $\begin{array}{l}\text { Application of } \\
\text { RCRA/ } \\
\text { Comprehensive } \\
\text { Environmental } \\
\text { Response, } \\
\text { Compensation, and } \\
\text { Liability Act } \\
\text { (CERCLA) }\end{array}$ & $\begin{array}{l}\text { Uncertainty of any } \\
\text { existing contamination } \\
\text { on application } \\
\text { (allocation) of } \\
\text { groundwater standards } \\
\text { to IDF. }\end{array}$ & $\begin{array}{l}\text { Groundwater may have existing } \\
\text { contamination from ongoing Hanford } \\
\text { operations. To what extent should this } \\
\text { contamination be considered in } \\
\text { allocating groundwater standards to } \\
\text { IDF? } \\
\text { Public perception issue }\end{array}$ & Need input from DOE & Need input from DOE \\
\hline
\end{tabular}




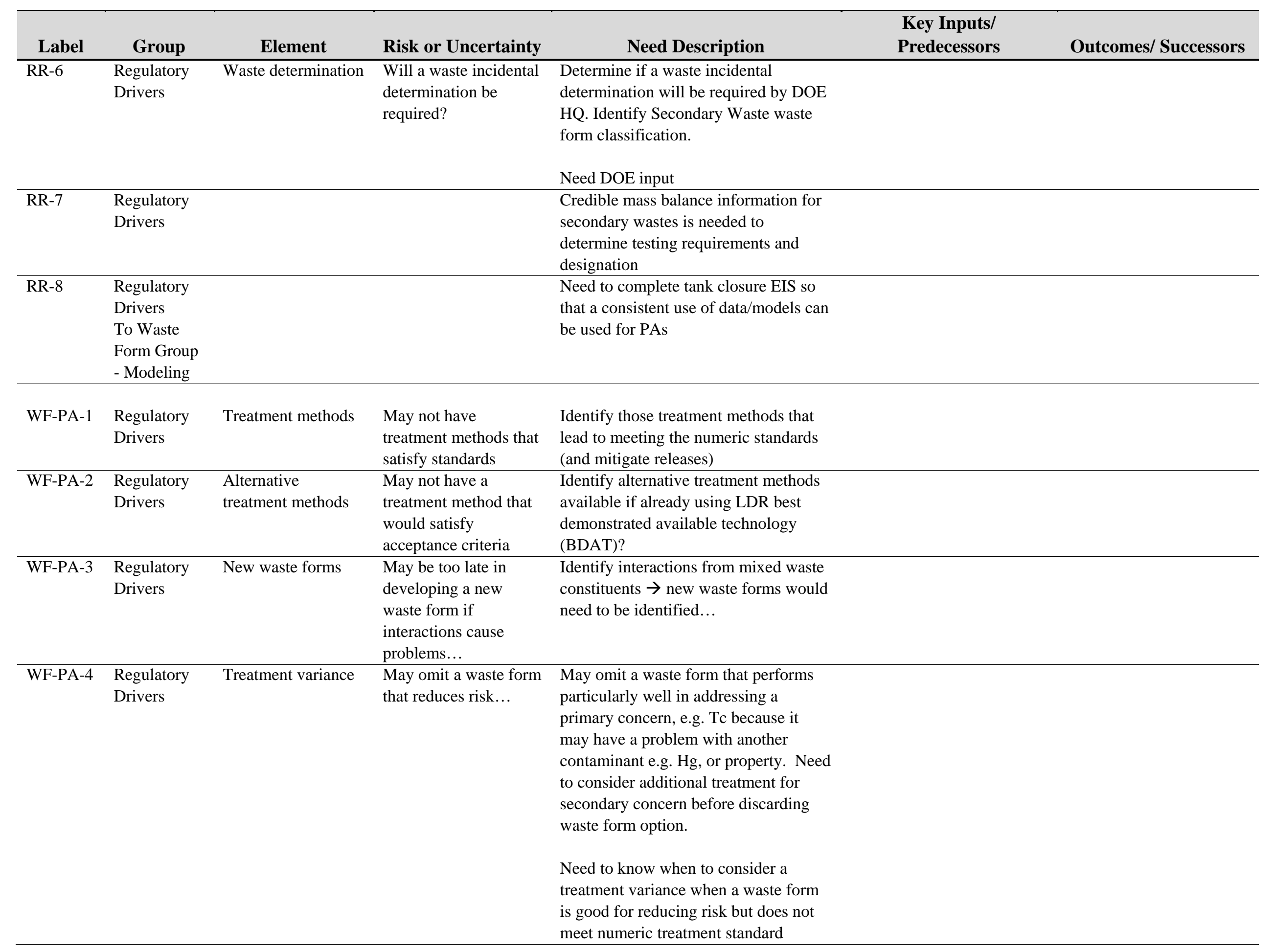




\begin{tabular}{|c|c|c|c|c|c|c|}
\hline & & & & & Key Inputs/ & \\
\hline Label & Group & Element & Risk or Uncertainty & Need Description & Predecessors & Outcomes/ Successors \\
\hline WF-PA-5 & $\begin{array}{l}\text { Regulatory } \\
\text { Drivers }\end{array}$ & Models & $\begin{array}{l}\text { May miss that model } \\
\text { predictions are } \\
\text { wrong-however, we } \\
\text { may miss something } \\
\text { important over } 10,000 \\
\text { years if looking at } \\
\text { short-term information }\end{array}$ & $\begin{array}{l}\text { Need to define (e.g., via monitoring) } \\
\text { when model predictions are wrong and } \\
\text { what needs to be done when they are } \\
\text { (e.g., new models) } \\
\text { (This may fall under the waste form } \\
\text { group PA \& contaminant release } \\
\text { mechanisms) }\end{array}$ & & \\
\hline RBT-1 & $\begin{array}{l}\text { Regulatory } \\
\text { Drivers }\end{array}$ & & & $\begin{array}{l}\text { How to decide or define that part of the } \\
\text { "overall risk budget" can/should be } \\
\text { attributed to the Secondary Wastes and } \\
\text { how to deal with changes and } \\
\text { uncertainties and impacts from other } \\
\text { facilities }\end{array}$ & & \\
\hline RBT-2 & $\begin{array}{l}\text { Regulatory } \\
\text { Drivers }\end{array}$ & $\begin{array}{l}\text { Environmental } \\
\text { standards? } \\
\text { Receptor risk } \\
\text { Radionuclide } \\
\text { Drinking Water } \\
\text { Standards }\end{array}$ & $\begin{array}{l}\text { Identify waste streams } \\
\text { contributing to } \\
\text { potential exceedance } \\
\text { of environmental } \\
\text { standards }\end{array}$ & $\begin{array}{l}\text { The WTP Permit Condition } \\
\text { III.10.C.2.n.iii - Identify those wastes } \\
\text { [contaminants?] that might cause or } \\
\text { significantly contribute to exceedance } \\
\text { of other environmental standards (GW) } \\
\text { This is specific to exceeding gross beta } \\
1 \mathrm{pCi} / \mathrm{L} \text { for Iodine129, and } 900 \mathrm{pCi} / \mathrm{L} \\
\text { for Tc99, and 4mrem critical organ } \\
\text { dose (cumulative) } \\
\text { Need to identify and characterize waste } \\
\text { steam(s) and their constituent(s) which, } \\
\text { following treatment and disposal in } \\
\text { IDF, may contribute to, in whole or } \\
\text { part, to exceedance of groundwater } \\
\text { radionuclide standards. } \\
\text { Add text from permit to main text }\end{array}$ & $\begin{array}{l}\text { Waste codes } \\
\text { Treatment Standards or } \\
\text { methods } \\
\text { Treatment methods }\end{array}$ & $\begin{array}{l}\text { Will be able to implement } \\
\text { the risk budgeting tool. } \\
\text { Provides guidance for } \\
\text { identifying treatment } \\
\text { technologies for key } \\
\text { radionuclides }\end{array}$ \\
\hline WAC-1 & $\begin{array}{l}\text { Regulatory } \\
\text { Drivers }\end{array}$ & $\begin{array}{l}\text { Performance } \\
\text { standards }\end{array}$ & $\begin{array}{l}\text { No understanding on } \\
\text { required accuracy and } \\
\text { relevance of technical } \\
\text { information for } \\
\text { regulatory decisions. } \\
\text { Inability to translate } \\
\text { performance } \\
\text { objectives into waste } \\
\text { form performance } \\
\text { standards }\end{array}$ & $\begin{array}{l}\text { Identify what it means (e.g., } \\
\text { measurements, estimates, etc.) to } \\
\text { perform to the appropriate standard for } \\
\text { Secondary Waste forms and what is the } \\
\text { required confidence? Determine } \\
\text { confidence level that is needed for } \\
\text { adequate technical data for the PA. } \\
\text { How to establish numeric comparison } \\
\text { values for PA? }\end{array}$ & $\begin{array}{l}\text { Receptor, fate/transport } \\
\text { pathway (IDF), regulatory } \\
\text { inputs (e.g., same as for } \\
\text { glass?) }\end{array}$ & $\begin{array}{l}\text { Response action that } \\
\text { allows Ecology/Energy to } \\
\text {... }\end{array}$ \\
\hline
\end{tabular}




\section{Appendix C}

Secondary Waste Treatment and Disposal Needs SummaryWaste Composition 


\section{Appendix C}

\section{Secondary Waste Treatment and Disposal Needs Summary-Waste Composition}

\begin{tabular}{|c|c|c|c|c|c|c|}
\hline Label & Group & Element & $\begin{array}{c}\text { Risk or } \\
\text { Uncertainty }\end{array}$ & Need Description & $\begin{array}{c}\text { Key } \\
\text { Inputs/Predecessors }\end{array}$ & Outcomes/Successors \\
\hline TI-1 & $\begin{array}{l}\text { Waste } \\
\text { Composition }\end{array}$ & Tank Inventory & $\begin{array}{l}\text { Source Term } \\
\text { Inventory and } \\
\text { Composition of } \\
\text { constituents of } \\
\text { concern }\end{array}$ & $\begin{array}{l}\text { Evaluation of existing data and } \\
\text { uncertainty within the context of } \\
\text { secondary waste formulation and } \\
\text { long term disposal assessment. } \\
\text { Specifically address: } \\
\text {-understanding Risk \& } \\
\text { Consequences } \\
\text {-Consider SRS \& other Data }\end{array}$ & $\begin{array}{l}\text {-current best basis } \\
\text { inventory (BBI) } \\
\text { - Hanford Defined } \\
\text { Waste (HDW) model } \\
\text { rev. 5. } \\
\text {-data from SRS } \\
\text { regarding form and } \\
\text { speciation of COCs }\end{array}$ & $\begin{array}{l}\text { An Understanding of the } \\
\text { range of uncertainty in } \\
\text { COC inventory } \\
\text { estimates, the expected } \\
\text { split between soluble } \\
\text { and insoluble phases }\end{array}$ \\
\hline TI-2 & $\begin{array}{l}\text { Waste } \\
\text { Composition }\end{array}$ & Tank Inventory & $\begin{array}{l}\text { Source Term } \\
\text { Inventory and } \\
\text { Composition of } \\
\text { constituents of } \\
\text { concern }\end{array}$ & $\begin{array}{l}\text { Evaluation of the cost and } \\
\text { benefits for additional uncertainty } \\
\text { reduction }\end{array}$ & $\begin{array}{l}\text { Understanding of COCs } \\
\text { important to secondary } \\
\text { waste disposal; the costs } \\
\text { of various secondary } \\
\text { waste treatment options } \\
\text { so that cost/uncertainty } \\
\text { comparisons can be } \\
\text { made }\end{array}$ & $\begin{array}{l}\text { A prioritized plan for } \\
\text { targeted sampling, } \\
\text { laboratory testing with } \\
\text { real and simulated } \\
\text { wastes, any additional } \\
\text { thermodynamic or } \\
\text { process modeling }\end{array}$ \\
\hline WR-1 & $\begin{array}{l}\text { Waste } \\
\text { Composition }\end{array}$ & $\begin{array}{l}\text { Impacts to } \\
\text { inventory and } \\
\text { chemistry }\end{array}$ & $\begin{array}{l}\text { Compositional } \\
\text { variability of COCs } \\
\text { resulting from } \\
\text { retrieval processes }\end{array}$ & $\begin{array}{l}\text { Evaluate partition function during } \\
\text { retrieval and the resultant } \\
\text { compositional uncertainties } \\
\text { (COCs) } \\
\text {-retrieval technology specific } \\
\text {-chemistry changes of COCs and } \\
\text { prediction of phase changes }\end{array}$ & $\begin{array}{l}\text {-BBI } \\
\text {-Range of retrieval } \\
\text { technologies }\end{array}$ & $\begin{array}{l}\text { An understanding of the } \\
\text { chemical and physical } \\
\text { changes occurring to the } \\
\text { COCs during the } \\
\text { retrieval and feed } \\
\text { staging processes; and } \\
\text { an understanding of the } \\
\text { range of uncertainties }\end{array}$ \\
\hline WR-2 & $\begin{array}{l}\text { Waste } \\
\text { Composition }\end{array}$ & $\begin{array}{l}\text { Impacts to } \\
\text { inventory and } \\
\text { chemistry }\end{array}$ & $\begin{array}{l}\text { Evaluation of the } \\
\text { cost and benefit of } \\
\text { additional } \\
\text { uncertainty reduction }\end{array}$ & $\begin{array}{l}\text { Determine if additional sampling } \\
\text { and characterization of wastes } \\
\text { during retrieval and waste } \\
\text { transfer is warranted; or if } \\
\text { laboratory testing supplemented } \\
\text { with process modeling is } \\
\text { adequate }\end{array}$ & $\begin{array}{l}\text {-BBI } \\
\text {-previous evaluation }\end{array}$ & $\begin{array}{l}\text { A prioritized plan } \\
\text { looking at targeted } \\
\text { sampling during the } \\
\text { retrieval process, } \\
\text { laboratory testing with } \\
\text { real and simulated } \\
\text { wastes, and needed } \\
\text { process modeling }\end{array}$ \\
\hline
\end{tabular}




\begin{tabular}{|c|c|c|c|c|c|c|}
\hline & & & Risk or & & Key & \\
\hline Label & Group & Element & Uncertainty & Need Description & Inputs/Predecessors & Outcomes/Successors \\
\hline WTP-1a & $\begin{array}{l}\text { Waste } \\
\text { Composition }\end{array}$ & WTP & $\begin{array}{l}\text { Flowsheet ‘splits' for } \\
\text { COCs }\end{array}$ & $\begin{array}{l}\text { Evaluation of the existing COC } \\
\text { partition function data and its } \\
\text { uncertainty in the context of } \\
\text { secondary waste disposal }\end{array}$ & $\begin{array}{l}\text {-WTP flowsheet models } \\
\text {-WTP research and } \\
\text { technology (R\&T) data } \\
\text { for COC performance } \\
\text {-identification of } \\
\text { primary drivers for } \\
\text { secondary waste } \\
\text { disposal } \\
\text {-lifecycle Hanford Tank } \\
\text { Waste Operations } \\
\text { Simulator (HTWOS) } \\
\text { model }\end{array}$ & \\
\hline WTP-1b & $\begin{array}{l}\text { Waste } \\
\text { Composition }\end{array}$ & & & 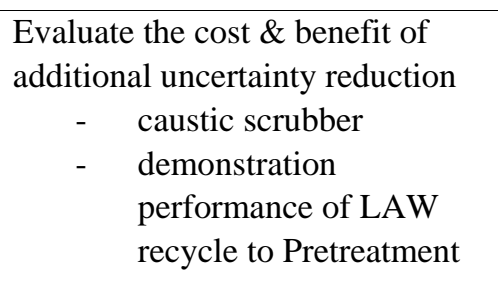 & & $\begin{array}{l}\text { Determination that } \\
\text { additional testing with } \\
\text { real waste or simulants } \\
\text { are required; additional } \\
\text { process and } \\
\text { thermodynamic } \\
\text { modeling is adequate }\end{array}$ \\
\hline WTP-2 & $\begin{array}{l}\text { Waste } \\
\text { Composition }\end{array}$ & $\begin{array}{l}\text { Waste treatment } \\
\text { flowsheet }\end{array}$ & $\begin{array}{l}\text { Need to consider } \\
\text { evolution of the } \\
\text { WTP flowsheet }\end{array}$ & $\begin{array}{l}\text { As ORP resolves sodium } \\
\text { management issues, the } \\
\text { secondary waste composition } \\
\text { may change }\end{array}$ & $\begin{array}{l}\text { ORP sodium } \\
\text { management plan }\end{array}$ & $\begin{array}{l}\text { Adequate margin in the } \\
\text { design and selection of } \\
\text { the secondary waste } \\
\text { form }\end{array}$ \\
\hline AWT-1a & $\begin{array}{l}\text { Waste } \\
\text { Composition }\end{array}$ & $\begin{array}{l}\text { Supplemental } \\
\text { Treatment }\end{array}$ & $\begin{array}{l}\text { Flowsheet splits for } \\
\text { COCs within } \\
\text { supplemental } \\
\text { treatment technology } \\
\text { options }\end{array}$ & $\begin{array}{l}\text { Supplemental treatment } \\
\text { technology decision (note: likely } \\
\text { that secondary waste decisions } \\
\text { will be made before supplemental } \\
\text { treatment technology decision) }\end{array}$ & & \\
\hline AWT-1b & $\begin{array}{l}\text { Waste } \\
\text { Composition }\end{array}$ & & & $\begin{array}{l}\text { Design of secondary waste } \\
\text { system should consider } \\
\text { (accommodate) potential for } \\
\text { added capacity and flexibility }\end{array}$ & $\begin{array}{l}\text { Supplemental treatment } \\
\text { technology options } \\
\text { Flowsheets for likely } \\
\text { deployment scenarios }\end{array}$ & $\begin{array}{l}\text { Provide to secondary } \\
\text { waste treatment system } \\
\text { range of estimates for } \\
\text { compositions, volumes, } \\
\text { and schedules }\end{array}$ \\
\hline AWT-2a & $\begin{array}{l}\text { Waste } \\
\text { Composition }\end{array}$ & Early LAW & $\begin{array}{l}\text { Impacts to COCs } \\
\text { during waste } \\
\text { treatment-flowsheet } \\
\text { splits/performance }\end{array}$ & $\begin{array}{l}\text { Decision on early LAW - } \\
\text { impacts the waste treatment } \\
\text { system configuration and } \\
\text { performance }\end{array}$ & & $\begin{array}{l}\text { Reflect Early LAW in } \\
\text { option evaluation until } \\
\text { decision is made }\end{array}$ \\
\hline AWT-2b & $\begin{array}{l}\text { Waste } \\
\text { Composition }\end{array}$ & & & $\begin{array}{l}\text { Evaluate if improved estimates of } \\
\text { COC performance in waste } \\
\text { treatment facilities during early } \\
\text { LAW is needed for uncertainty } \\
\text { reduction }\end{array}$ & $\begin{array}{l}\text {-Understanding of } \\
\text { flexibility of secondary } \\
\text { waste treatment options } \\
\text {-flowsheet models for } \\
\text { WTP, ETF when } \\
\text { supporting early LAW }\end{array}$ & $\begin{array}{l}\text { A determination if } \\
\text { additional testing or } \\
\text { modeling is necessary to } \\
\text { make decisions } \\
\text { regarding secondary } \\
\text { waste management } \\
\text { during early LAW } \\
\text { operations }\end{array}$ \\
\hline
\end{tabular}




\begin{tabular}{|c|c|c|c|c|c|c|}
\hline Label & Group & Element & $\begin{array}{c}\text { Risk or } \\
\text { Uncertainty }\end{array}$ & Need Description & $\begin{array}{c}\text { Key } \\
\text { Inputs/Predecessors }\end{array}$ & Outcomes/Successors \\
\hline AWT-2c & $\begin{array}{l}\text { Waste } \\
\text { Composition }\end{array}$ & & & $\begin{array}{l}\text { How does technology selected } \\
\text { for early LAW pretreatment } \\
\text { impact balance of treatment } \\
\text { mission and secondary waste } \\
\text { management strategy }\end{array}$ & $\begin{array}{l}\text {-Early LAW flowsheet } \\
\text {-interim pretreatment } \\
\text { technology options } \\
\text {-feed selection (specific } \\
\text { tanks) }\end{array}$ & $\begin{array}{l}\text { Determination if } \\
\text { additional testing and/or } \\
\text { modeling is required }\end{array}$ \\
\hline SIM-1 & $\begin{array}{l}\text { Waste } \\
\text { Composition }\end{array}$ & $\begin{array}{l}\text { Secondary Waste } \\
\text { Simulants and } \\
\text { surrogates }\end{array}$ & $\begin{array}{l}\text { Secondary waste } \\
\text { form development } \\
\text { robust enough to } \\
\text { cover range of } \\
\text { uncertainty }\end{array}$ & $\begin{array}{l}\text { Develop a reasonable range of } \\
\text { secondary waste simulants for } \\
\text { secondary waste form } \\
\text { development }\end{array}$ & $\begin{array}{l}\text { Flowsheet and } \\
\text { uncertainty work from } \\
\text { tank inventory, WTP } \\
\text { and supplemental } \\
\text { treatment tasks above }\end{array}$ & $\begin{array}{l}\text { Simulants that cover the } \\
\text { range of potential } \\
\text { technologies and } \\
\text { configurations of the } \\
\text { waste treatment system }\end{array}$ \\
\hline SIM-2 & $\begin{array}{l}\text { Waste } \\
\text { Composition }\end{array}$ & $\begin{array}{l}\text { Secondary Waste } \\
\text { Simulants and } \\
\text { surrogates }\end{array}$ & $\begin{array}{l}\text { Processes will vary } \\
\text { over time. } \\
\text { Uncertainty in } \\
\text { projecting future } \\
\text { waste compositions }\end{array}$ & $\begin{array}{l}\text { Need to address uncertainties and } \\
\text { process variability (notes from } \\
\text { yellow chart) }\end{array}$ & $\begin{array}{l}\text { Results of uncertainty } \\
\text { and variability analyses } \\
\text { from waste Inventory } \\
\text { and waste treatment } \\
\text { tasks }\end{array}$ & $\begin{array}{l}\text { Process variability and } \\
\text { uncertainty addressed in } \\
\text { secondary waste system } \\
\text { design and waste form } \\
\text { development }\end{array}$ \\
\hline SIM-3 & $\begin{array}{l}\text { Waste } \\
\text { Composition }\end{array}$ & $\begin{array}{l}\text { Secondary Waste } \\
\text { Simulants and } \\
\text { surrogates }\end{array}$ & $\begin{array}{l}\text { Non radioactive } \\
\text { Surrogates are } \\
\text { necessary for large } \\
\text { scale testing and } \\
\text { evaluation }\end{array}$ & $\begin{array}{l}\text { Surrogates do not mimic } \\
\text { radioactive waste for all purposes }\end{array}$ & $\begin{array}{l}\text { If surrogates are used, a } \\
\text { validation plan, } \\
\text { including testing with } \\
\text { real wastes is required. } \\
\text { Make sure that tests are } \\
\text { designed to answer } \\
\text { specific questions. Not } \\
\text { possible to simulate } \\
\text { everything for all } \\
\text { purposes in a single } \\
\text { surrogate test }\end{array}$ & $\begin{array}{l}\text { Adequate design margin } \\
\text { for secondary waste } \\
\text { system and waste form. }\end{array}$ \\
\hline
\end{tabular}


Appendix D

Secondary Waste Treatment and Disposal Needs SummaryWaste Form 


\section{Appendix D}

\section{Secondary Waste Treatment and Disposal Needs Summary-Waste Form}

\begin{tabular}{|c|c|c|c|c|c|c|}
\hline Label & Group & Element & $\begin{array}{c}\text { Risk or } \\
\text { Uncertainty } \\
\end{array}$ & Need Description & $\begin{array}{c}\text { Key } \\
\text { Inputs/Predecessors } \\
\end{array}$ & Outcomes/Successors \\
\hline WFS-1 & $\begin{array}{l}\text { Waste } \\
\text { Form }\end{array}$ & $\begin{array}{l}\text { Waste Form } \\
\text { Evaluation and } \\
\text { Selection }\end{array}$ & $\begin{array}{l}\text { Level of maturation } \\
\text { for forms other than } \\
\text { glass and cement. } \\
\text { Do we have accepted } \\
\text { standards for } \\
\text { selection or will } \\
\text { round robin testing } \\
\text { be required? }\end{array}$ & $\begin{array}{l}\text { Way of comparing apples and oranges } \\
\text { and deciding how to compare on a } \\
\text { level playing field. A way to verify } \\
\text { objectivity in the evaluation and not } \\
\text { eliminate waste forms that might be } \\
\text { promising just b/c they're less mature. } \\
\text { Need a set of tests (ideally consensus } \\
\text { standards) or process to evaluate and } \\
\text { compare the performance of a specific } \\
\text { class of waste forms against each } \\
\text { active release mechanism }\end{array}$ & $\begin{array}{l}\text { Development timeframes } \\
\text { to what level of maturity } \\
\text { Cost to develop } \\
\text { Expected performance, } \\
\text { cost, and maturity }\end{array}$ & Objective comparison \\
\hline WFS-2 & $\begin{array}{l}\text { Waste } \\
\text { Form }\end{array}$ & $\begin{array}{l}\text { Waste Form } \\
\text { Evaluation and } \\
\text { Selection }\end{array}$ & $\begin{array}{l}\text { What screening } \\
\text { processes, tests, etc. } \\
\text { can be applied to } \\
\text { narrow options? }\end{array}$ & $\begin{array}{l}\text { Need a way to narrow large number } \\
\text { among and within waste form options } \\
\text { under consideration in absence of } \\
\text { verified and consistent information on } \\
\text { waste form release mechanisms } \\
\text { and/or processes. } \\
\text { "Early" process to narrow potential } \\
\text { waste form options } \\
\text { Need an iterative process... }\end{array}$ & $\begin{array}{l}\text { Expected performance, } \\
\text { cost, and maturity (TRA) } \\
\\
\text { Best available WAC and } \\
\text { baseline composition info } \\
\text { Extent of stakeholder/ } \\
\text { regulator acceptance } \\
\text { Objective decision criteria }\end{array}$ & $\begin{array}{l}\text { Shortened list of } \\
\text { candidate waste forms }\end{array}$ \\
\hline WFS-3a & $\begin{array}{l}\text { Waste } \\
\text { Form }\end{array}$ & $\begin{array}{l}\text { Contaminant } \\
\text { Release }\end{array}$ & $\begin{array}{l}\text { Test methods are not } \\
\text { adequate to } \\
\text { understand the } \\
\text { release mechanisms }\end{array}$ & $\begin{array}{l}\text { Need appropriate test methods } \\
\text { Need to know what kind of certainty } \\
\text { (how much) the test methods provide }\end{array}$ & $\begin{array}{l}\text { - List of the COCs } \\
\text { - Disposal environment } \\
\text { - PA scenarios } \\
\text { - Potential release } \\
\text { mechanisms } \\
\text { - Current proposed test } \\
\text { methods }\end{array}$ & $\begin{array}{l}\text { Confidence that you } \\
\text { understand the release } \\
\text { mechanism } \\
\text { Confidence that you are } \\
\text { accounting for aging } \\
\text { Information to support } \\
\text { the test methods (or } \\
\text { change them) }\end{array}$ \\
\hline
\end{tabular}




\begin{tabular}{|c|c|c|c|c|c|c|}
\hline & & & Risk or & & Key & \\
\hline Label & Group & Element & Uncertainty & Need Description & Inputs/Predecessors & Outcomes/Successors \\
\hline \multirow[t]{4}{*}{ WFS-3b } & \multirow[t]{4}{*}{$\begin{array}{l}\text { Waste } \\
\text { Form }\end{array}$} & & $\begin{array}{l}\text { Test methods are not } \\
\text { adequate to reflect } \\
\text { the release }\end{array}$ & $\begin{array}{l}\text { Need consensus from wide range of } \\
\text { stakeholders that the test methods will } \\
\text { be satisfactory }\end{array}$ & \multirow{4}{*}{$\begin{array}{l}\text { Current proposed test } \\
\text { methods } \\
\text { Results of previous row }\end{array}$} & $\begin{array}{l}\text { Identification of a need } \\
\text { to develop a new test } \\
\text { method (possiblv) }\end{array}$ \\
\hline & & & mechanisms or rates & & & \\
\hline & & & $\begin{array}{l}\text { of release (this } \\
\text { means: your test } \\
\text { might not accurately } \\
\text { represent the } \\
\text { mechanism or }\end{array}$ & $\begin{array}{l}\text { Need a test method(s) (maybe } \\
\text { accelerated) that is a reasonable stand } \\
\text { in for long-term performance }{ }^{(\mathrm{a})}\end{array}$ & & $\begin{array}{l}\text { Ability to screen or rank } \\
\text { waste form performance } \\
\text { as a function of aging } \\
\text { scenarios }\end{array}$ \\
\hline & & & mechanisms) & & & $\begin{array}{l}\text { Short-term test that can } \\
\text { be used to set interim } \\
\text { quantitative waste form } \\
\text { limits consistent with PA } \\
\text { scenarios but pending } \\
\text { final PA outcomes }\end{array}$ \\
\hline \multirow[t]{4}{*}{ WFS-4 } & \multirow[t]{4}{*}{$\begin{array}{l}\text { Waste } \\
\text { Form }\end{array}$} & \multirow{4}{*}{$\begin{array}{l}\text { Waste Form } \\
\text { Evaluation and } \\
\text { Selection }\end{array}$} & \multirow{4}{*}{$\begin{array}{l}\text { Economic factors- } \\
\text { costs and how they } \\
\text { play into selection }\end{array}$} & Method for cost comparison & $\begin{array}{l}\text { prelim design } \\
\text { waste loadings }\end{array}$ & $\begin{array}{l}\text { comparable cost } \\
\text { estimates for alternatives }\end{array}$ \\
\hline & & & & $\begin{array}{l}\text { Reasonable and defensible set of cost } \\
\text { estimates that you can compare }\end{array}$ & $\begin{array}{l}\text { materials } \\
\text { material }\end{array}$ & \\
\hline & & & & $\begin{array}{l}\text { between for alternatives (including } \\
\text { design, development, }\end{array}$ & $\begin{array}{l}\text { balance/flowsheet } \\
\text { volume }\end{array}$ & \\
\hline & & & & $\begin{array}{l}\text { implementation/processing and } \\
\text { disposal) }\end{array}$ & special containers & \\
\hline \multirow[t]{5}{*}{ WFS-5 } & \multirow[t]{5}{*}{$\begin{array}{l}\text { Waste } \\
\text { Form }\end{array}$} & \multirow[t]{5}{*}{$\begin{array}{l}\text { Waste Form } \\
\text { Evaluation and } \\
\text { Selection }\end{array}$} & \multirow{5}{*}{$\begin{array}{l}\text { What screening } \\
\text { processes, tests, etc. } \\
\text { can be applied to } \\
\text { narrow options } \\
\text { within waste form } \\
\text { class? }\end{array}$} & $\begin{array}{l}\text { Interim test program and methods for } \\
\text { waste form development in advance } \\
\text { of PA requirements (product }\end{array}$ & $\begin{array}{l}\text { Expected performance, } \\
\text { cost, and maturity }\end{array}$ & \\
\hline & & & & consistency test [PCT] vs. single-pass & Best available WAC and & \\
\hline & & & & $\begin{array}{l}\text { flow through [SPFT] as an example } \\
\text { for glass) }\end{array}$ & baseline composition info & \\
\hline & & & & & $\begin{array}{l}\text { Extent of stakeholder/ } \\
\text { regulator acceptance }\end{array}$ & \\
\hline & & & & & Objective decision criteria & \\
\hline \multirow[t]{3}{*}{ WFS-6 } & \multirow[t]{3}{*}{$\begin{array}{l}\text { Waste } \\
\text { Form }\end{array}$} & \multirow[t]{3}{*}{$\begin{array}{l}\text { Waste Form } \\
\text { Development }\end{array}$} & \multirow{3}{*}{$\begin{array}{l}\text { Can pretreatment } \\
\text { effectively manage } \\
\text { some COCs or to } \\
\text { improve system } \\
\text { performance }\end{array}$} & $\begin{array}{l}\text { Need to know if proposed waste form } \\
\text { can effectively contain all COC or } \\
\text { would a pretreatment step be more } \\
\text { effective/cost-effective (e.g. }\end{array}$ & $\begin{array}{l}\text { Preliminary waste form } \\
\text { performance data (e.g., } \\
\text { leaching) }\end{array}$ & $\begin{array}{l}\text { Cost/benefit analysis of } \\
\text { various treatment train } \\
\text { options }\end{array}$ \\
\hline & & & & $\begin{array}{l}\text { pretreatment to destroy nitrates, or } \\
\text { reduce Tc) }\end{array}$ & $\begin{array}{l}\text { Preliminary waste form } \\
\text { data on waste loading } \\
\text { improvements }\end{array}$ & $\begin{array}{l}\text { Performance and waste } \\
\text { loading data }\end{array}$ \\
\hline & & & & $\begin{array}{l}\text { Need to know if pretreatment would } \\
\text { generate a tertiary waste stream }\end{array}$ & Data on costs/benefits & \\
\hline
\end{tabular}

(a) Types of tests: set of test to understand the mechanism, set of test to represent performance, set of tests to derive rate constants/rate data; set of accelerated tests to mimic long-term aging and system performance 


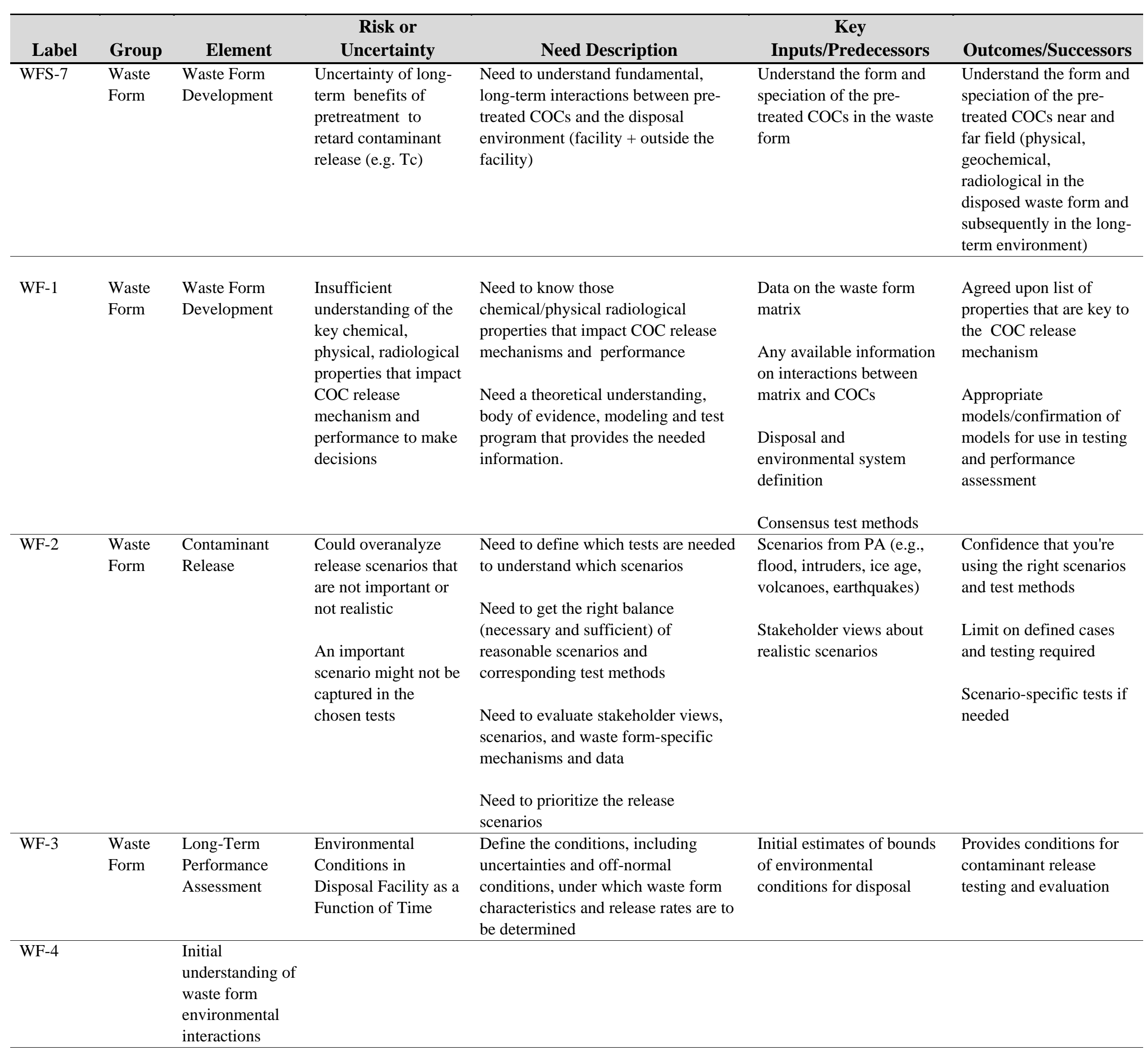




\begin{tabular}{|c|c|c|c|c|c|c|}
\hline Label & Group & Element & $\begin{array}{c}\text { Risk or } \\
\text { Uncertainty }\end{array}$ & Need Description & $\begin{array}{c}\text { Key } \\
\text { Inputs/Predecessors }\end{array}$ & Outcomes/Successors \\
\hline TM-1 & $\begin{array}{l}\text { Waste } \\
\text { Form }\end{array}$ & $\begin{array}{l}\text { Testing } \\
\text { Methodologies }\end{array}$ & $\begin{array}{l}\text { Trying to accelerate } \\
\text { may change COCs } \\
\text { release behavior } \\
\text { (e.g., temperature } \\
\text { may change the form } \\
\text { of Tc and therefore } \\
\text { change how it is } \\
\text { released) }\end{array}$ & $\begin{array}{l}\text { Need to understand the stability and } \\
\text { properties of COCs and waste form } \\
\text { matrix under the full range of } \\
\text { proposed accelerated conditions }\end{array}$ & $\begin{array}{l}\text { Existing body of evidence } \\
\text { (e.g., data and literature } \\
\text { review) } \\
\text { Data gap analysis }\end{array}$ & Testing to fill data gaps \\
\hline TM-2 & $\begin{array}{l}\text { Waste } \\
\text { Form }\end{array}$ & $\begin{array}{l}\text { Testing } \\
\text { Methodologies }\end{array}$ & $\begin{array}{l}\text { Accelerated testing } \\
\text { might not adequately } \\
\text { reflect long-term } \\
\text { behavior }\end{array}$ & $\begin{array}{l}\text { Need to determine whether the test, } \\
\text { applied to the specific waste form } \\
\text { represents long-term performance, is } \\
\text { appropriate for the specific waste } \\
\text { form and the specific property you're } \\
\text { investigating } \\
\text { Need to determine how to predict } \\
\text { long-term behavior from short-term } \\
\text { [accelerated] data/information }\end{array}$ & 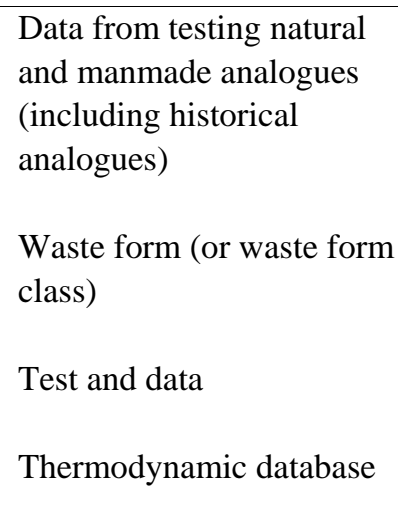 & $\begin{array}{l}\text { Conceptual model of } \\
\text { waste form aging and } \\
\text { release (behavior) for the } \\
\text { PA } \\
\text { Set of improved or new } \\
\text { accelerated tests or better } \\
\text { confidence in existing } \\
\text { tests } \\
\text { Thermodynamic } \\
\text { predictions }\end{array}$ \\
\hline TM-3 & $\begin{array}{l}\text { Waste } \\
\text { Form }\end{array}$ & $\begin{array}{l}\text { Testing } \\
\text { Methodologies }\end{array}$ & $\begin{array}{l}\text { Cured samples may } \\
\text { not have same } \\
\text { properties of the } \\
\text { ultimately disposed } \\
\text { waste form } \\
\text { Samples may cure at } \\
\text { different rates }\end{array}$ & $\begin{array}{l}\text { Need consistent methods for curing } \\
\text { samples and projecting the mineral } \\
\text { composition and key chemical and } \\
\text { physical properties to the ultimate } \\
\text { waste form }\end{array}$ & $\begin{array}{l}\text { Quality control } \\
\text { Characteristics as a } \\
\text { function of curing time } \\
\text { Existing process } \\
\text { knowledge (existing body } \\
\text { of knowledge) } \\
\text { Present data on waste } \\
\text { form materials }\end{array}$ & $\begin{array}{l}\text { Consensus sample curing } \\
\text { method for that waste } \\
\text { form } \\
\text { Sample curing method to } \\
\text { predict ultimate waste } \\
\text { form performance }\end{array}$ \\
\hline TM-4 & $\begin{array}{l}\text { Waste } \\
\text { Form }\end{array}$ & $\begin{array}{l}\text { Waste Form } \\
\text { Development }\end{array}$ & $\begin{array}{l}\text { Waste forms may } \\
\text { perform differently at } \\
\text { different scales }\end{array}$ & $\begin{array}{l}\text { Need to know the final scale - what } \\
\text { does full scale means for this waste } \\
\text { form process } \\
\text { Need to know what scale is necessary } \\
\text { to validate the process } \\
\text { Need to demonstrate the final waste } \\
\text { form process at full scale }\end{array}$ & $\begin{array}{l}\text { Scale up testing results } \\
\text { (results of testing to feed } \\
\text { process parameters for } \\
\text { scale up) } \\
\text { Identification of process } \\
\text { technology/equipment }\end{array}$ & $\begin{array}{l}\text { Confidence in full scale } \\
\text { performance }\end{array}$ \\
\hline
\end{tabular}




\begin{tabular}{|c|c|c|c|c|c|c|}
\hline & & & Risk or & & Key & \\
\hline Label & Group & Element & Uncertainty & Need Description & Inputs/Predecessors & Outcomes/Successors \\
\hline \multirow[t]{5}{*}{ WFA-1 } & $\begin{array}{l}\text { Waste } \\
\text { Form }\end{array}$ & $\begin{array}{l}\text { Long-Term } \\
\text { Performance } \\
\text { Assessment }\end{array}$ & Waste Form Aging & $\begin{array}{l}\text { Release rates for the long term } \\
\text { (thousand years) }\end{array}$ & $\begin{array}{l}\text { Conditions to consider in } \\
\text { developing understanding } \\
\text { of waste form aging }\end{array}$ & $\begin{array}{l}\text { Models of waste form } \\
\text { aging for use in } \\
\text { performance assessment }\end{array}$ \\
\hline & & & & $\begin{array}{l}\text { Changes in physical properties/ } \\
\text { degradation of waste form }\end{array}$ & & \\
\hline & & & & $\begin{array}{l}\text { Need from performance assessment } \\
\text { the scenarios to assess the } \\
\text { characteristics and performance of the } \\
\text { waste form }\end{array}$ & & \\
\hline & & & & $\begin{array}{l}\text { Define the conditions to be } \\
\text { considered in examining long term } \\
\text { waste form behavior }\end{array}$ & & \\
\hline & & & & $\begin{array}{l}\text { How do those changes in waste form } \\
\text { aging impact the release rate }\end{array}$ & & \\
\hline \multirow[t]{3}{*}{ WFA-2 } & $\begin{array}{l}\text { Waste } \\
\text { Form }\end{array}$ & $\begin{array}{l}\text { Testing } \\
\text { Methodologies }\end{array}$ & $\begin{array}{l}\text { Don't have an } \\
\text { adequate } \\
\text { understanding of } \\
\text { aging processes }\end{array}$ & $\begin{array}{l}\text { Need to identify aging processes } \\
\text { Need testing methods that identify } \\
\text { and mimic aging processes }\end{array}$ & $\begin{array}{l}\text { Properties of COCs and } \\
\text { waste form matrix and } \\
\text { disposal environment }\end{array}$ & $\begin{array}{l}\text { Input into the PA } \\
\text { Improves understanding } \\
\text { of the aging process }\end{array}$ \\
\hline & & & & $\begin{array}{l}\text { Characteristics and consequences of } \\
\text { the aging processes }\end{array}$ & $\begin{array}{l}\text { Natural or manmade } \\
\text { analogues }\end{array}$ & $\begin{array}{l}\text { Improved confidence in } \\
\text { the waste form }\end{array}$ \\
\hline & & & & & $\begin{array}{l}\text { American Society for } \\
\text { Testing and Materials } \\
\text { (ASTM) C-1174 (a } \\
\text { protocol to predict long } \\
\text { term performance from } \\
\text { short term tests) }\end{array}$ & \\
\hline \multirow[t]{3}{*}{ WFA-3 } & $\begin{array}{l}\text { Waste } \\
\text { Form }\end{array}$ & $\begin{array}{l}\text { Contaminant } \\
\text { Release }\end{array}$ & $\begin{array}{l}\text { Don't know how to } \\
\text { account for aging in } \\
\text { waste form } \\
\text { development }\end{array}$ & $\begin{array}{l}\text { Need to define aging scenarios that } \\
\text { are considered in the PA (e.g., } \\
\text { flooding, erosion, carbonation, } \\
\text { subsidence, cracking, ice age, } \\
\text { microbial and radiolysis and time } \\
\text { frame, etc.) }\end{array}$ & $\begin{array}{l}\text { List of aging scenarios } \\
\text { Correct release mechanism } \\
\text { and how to accelerate it } \\
\text { without changing it } \\
\text { Disposal environment }\end{array}$ & $\begin{array}{l}\text { Leach rate data or } \\
\text { equation/expression, } \\
\text { parameters and } \\
\text { mechanism as a function } \\
\text { of aging phenomena } \\
\text { (will provide inputs to } \\
\text { the model) }\end{array}$ \\
\hline & & & & $\begin{array}{l}\text { Need to know the ways the waste } \\
\text { form itself will age (e.g., phase } \\
\text { change) }\end{array}$ & PA scenarios & $\begin{array}{l}\text { Test protocols to address } \\
\text { aging }\end{array}$ \\
\hline & & & & $\begin{array}{l}\text { Need to understand how to } \\
\text { appropriately extrapolate and } \\
\text { accelerate testing to understand how } \\
\text { the release mechanism will behave } \\
\text { over time in the disposal environment }\end{array}$ & & \\
\hline
\end{tabular}




\begin{tabular}{|c|c|c|c|c|c|c|}
\hline Label & Group & Element & $\begin{array}{c}\text { Risk or } \\
\text { Uncertainty }\end{array}$ & Need Description & $\begin{array}{c}\text { Key } \\
\text { Inputs/Predecessors }\end{array}$ & Outcomes/Successors \\
\hline WFA-4 & $\begin{array}{l}\text { Waste } \\
\text { Form }\end{array}$ & $\begin{array}{l}\text { Waste Form } \\
\text { Development }\end{array}$ & $\begin{array}{l}\text { Radiological } \\
\text { damage/stability } \\
\text { taken into account? }\end{array}$ & $\begin{array}{l}\text { Need to know whether radiation will } \\
\text { damage the waste form and/or affect } \\
\text { the release mechanism } \\
\text { Need to know whether co-disposal } \\
\text { with radiologically active wastes will } \\
\text { affect the waste form } \\
\text { Need to know whether secondary } \\
\text { wastes should be isolated through } \\
\text { administrative controls }\end{array}$ & $\begin{array}{l}\text { Co disposal configuration } \\
\text { Rad inventories } \\
\text { Packaging } \\
\text { technology/types of } \\
\text { containers and design }\end{array}$ & $\begin{array}{l}\text { Technical basis for } \\
\text { administrative controls } \\
\text { Might drive a need for } \\
\text { specific testing }\end{array}$ \\
\hline WFA-5 & $\begin{array}{l}\text { Waste } \\
\text { Form }\end{array}$ & $\begin{array}{l}\text { Contaminant } \\
\text { Release }\end{array}$ & $\begin{array}{l}\text { Non-aqueous release } \\
\text { mechanisms may be } \\
\text { overlooked (e.g., } \\
\text { Iodine vapor) }\end{array}$ & $\begin{array}{l}\text { Need to consider non-aqueous } \\
\text { pathways and rule them in or out [see } \\
\text { release mechanism understanding } \\
\text { stuff above] }\end{array}$ & $\begin{array}{l}\text { Phase behavior for COCs } \\
\text { Temperature of disposal } \\
\text { system } \\
\text { Vapor pressure for specific } \\
\text { COCs }\end{array}$ & $\begin{array}{l}\text { Correct release } \\
\text { mechanism is } \\
\text { determined } \\
\text { Conditions under which } \\
\text { vapor is a problem are } \\
\text { understood } \\
\text { Phases are accounted for }\end{array}$ \\
\hline DI-1 & $\begin{array}{l}\text { Waste } \\
\text { Form }\end{array}$ & $\begin{array}{l}\text { Disposal System } \\
\text { Interactions }\end{array}$ & $\begin{array}{l}\text { Impact on waste } \\
\text { performance of a } \\
\text { changed surface } \\
\text { environment }\end{array}$ & $\begin{array}{l}\text { An assessment of the impact of a } \\
\text { changed surface environment on the } \\
\text { disposal system performance (e.g. } \\
\text { increased nitrate from fertilizer). The } \\
\text { assessment should include intruder } \\
\text { scenarios }\end{array}$ & $\begin{array}{l}\text { Credible changed } \\
\text { environmental condition } \\
\text { scenarios } \\
\text { Intruder scenarios }\end{array}$ & $\begin{array}{l}\text { Performance of the waste } \\
\text { forms as part of the } \\
\text { disposal system. } \\
\text { Affects waste form } \\
\text { selection, waste } \\
\text { acceptance criteria, } \\
\text { disposal system design }\end{array}$ \\
\hline DI-2 & $\begin{array}{l}\text { Waste } \\
\text { Form }\end{array}$ & $\begin{array}{l}\text { Disposal System } \\
\text { Interactions }\end{array}$ & $\begin{array}{l}\text { Impact to vadose } \\
\text { zone/groundwater } \\
\text { outside disposal } \\
\text { facility }\end{array}$ & $\begin{array}{l}\text { An assessment of the impact of the } \\
\text { leachates on the transport of } \\
\text { contaminants beneath the disposal } \\
\text { facility }\end{array}$ & Leachate composition & $\begin{array}{l}\text { Performance of the waste } \\
\text { forms as part of the } \\
\text { disposal system. } \\
\text { Affects waste form } \\
\text { selection, waste } \\
\text { acceptance criteria, } \\
\text { disposal system design }\end{array}$ \\
\hline DI-3 & $\begin{array}{l}\text { Waste } \\
\text { Form }\end{array}$ & $\begin{array}{l}\text { Disposal System } \\
\text { Interactions }\end{array}$ & $\begin{array}{l}\text { Impacts to other parts } \\
\text { of facility (materials } \\
\text { compatibility), }\end{array}$ & $\begin{array}{l}\text { An assessment of the impact of the } \\
\text { waste form, e.g., leachate, fine grain } \\
\text { particulates or overweight waste form } \\
\text { on disposal system components } \\
\text { beneath the wastes }\end{array}$ & $\begin{array}{l}\text { Leachate composition } \\
\text { Waste form weight loading } \\
\text { on disposal system }\end{array}$ & $\begin{array}{l}\text { Performance of the waste } \\
\text { forms as part of the } \\
\text { disposal system. } \\
\text { Affects waste form } \\
\text { selection, waste } \\
\text { acceptance criteria, } \\
\text { disposal system design }\end{array}$ \\
\hline
\end{tabular}




\begin{tabular}{|c|c|c|c|c|c|c|}
\hline Label & Group & Element & $\begin{array}{c}\text { Risk or } \\
\text { Uncertainty }\end{array}$ & Need Description & $\begin{array}{c}\text { Key } \\
\text { Inputs/Predecessors }\end{array}$ & Outcomes/Successors \\
\hline DI-4 & $\begin{array}{l}\text { Waste } \\
\text { Form }\end{array}$ & $\begin{array}{l}\text { Disposal System } \\
\text { Interactions }\end{array}$ & $\begin{array}{l}\text { Impact to surface } \\
\text { barrier (subsidence) }\end{array}$ & $\begin{array}{l}\text { An assessment of the impact of waste } \\
\text { forms on the upper barrier. Need to } \\
\text { minimize subsidence or expansion } \\
\text { leading to compromise of surface } \\
\text { barrier }\end{array}$ & $\begin{array}{l}\text { Compressive strength and } \\
\text { volume changes as a } \\
\text { function of time and } \\
\text { disposal environment }\end{array}$ & $\begin{array}{l}\text { Performance of the waste } \\
\text { forms as part of the } \\
\text { disposal system. } \\
\text { Affects waste form } \\
\text { selection, waste } \\
\text { acceptance criteria, } \\
\text { disposal system design }\end{array}$ \\
\hline DI-5 & $\begin{array}{l}\text { Waste } \\
\text { Form }\end{array}$ & $\begin{array}{l}\text { Disposal System } \\
\text { Interactions }\end{array}$ & $\begin{array}{l}\text { Impacts of waste } \\
\text { form interactions } \\
\text { among co-disposed } \\
\text { forms }\end{array}$ & $\begin{array}{l}\text { An assessment of the impacts of } \\
\text { various waste forms on the release } \\
\text { rates of each waste form in the } \\
\text { disposal facility, for example } \\
\text { temperature, moisture, aqueous } \\
\text { chemical environment (pH, eH, } \\
\text { composition), gamma dose, supported } \\
\text { by adequate testing and modeling. }\end{array}$ & $\begin{array}{l}\text { Inventories of co-disposed } \\
\text { waste forms and } \\
\text { performance parameters } \\
\text { Disposal conditions }\end{array}$ & $\begin{array}{l}\text { Performance of the waste } \\
\text { forms as part of the } \\
\text { disposal system. } \\
\text { Affects waste form } \\
\text { selection, waste } \\
\text { acceptance criteria, } \\
\text { disposal system design }\end{array}$ \\
\hline DI-6 & $\begin{array}{l}\text { Waste } \\
\text { Form }\end{array}$ & $\begin{array}{l}\text { Long-Term } \\
\text { Performance } \\
\text { Assessment }\end{array}$ & $\begin{array}{l}\text { Change in Chemical } \\
\text { Form of Contaminant } \\
\text { in Disposal } \\
\text { Environment } \\
\text { (Single waste form) }\end{array}$ & $\begin{array}{l}\text { Need model that takes into account } \\
\text { changes in the chemical form of the } \\
\text { contaminant and its impact on } \\
\text { contaminant release (for example } \\
\text { from secondary waste } \\
\text { pretreatment/treatment, } \\
\text { immobilization disposal facility } \\
\text { design). }\end{array}$ & $\begin{array}{l}\text { Secondary Waste } \\
\text { Composition } \\
\text { Plans for secondary waste } \\
\text { treatment processes } \\
\text { Processes/models for } \\
\text { chemical transitions in the } \\
\text { waste form/vadose zone }\end{array}$ & $\begin{array}{l}\text { Secondary waste } \\
\text { pretreatment/treatment } \\
\text { process selection }\end{array}$ \\
\hline PAM-1 & $\begin{array}{l}\text { Waste } \\
\text { Form }\end{array}$ & $\begin{array}{l}\text { Contaminant } \\
\text { Release }\end{array}$ & $\begin{array}{l}\text { What expression will } \\
\text { be used to express } \\
\text { release rate } \\
\text { mechanism-how to } \\
\text { model the selected } \\
\text { release mechanism }\end{array}$ & $\begin{array}{l}\text { Need to confirm or modify the release } \\
\text { rate model to accommodate changes } \\
\text { in release rate as a function of aging } \\
\text { [Addressed in the waste form } \\
\text { development chart in the translation } \\
\text { thing] }\end{array}$ & $\begin{array}{l}\text { Basic model \& parameters } \\
\text { Release rate test data } \\
\text { List of COCs } \\
\text { Aging scenario(s) }\end{array}$ & $\begin{array}{l}\text { Confirming the model in } \\
\text { use or modifying it }\end{array}$ \\
\hline PAM-2 & $\begin{array}{l}\text { Waste } \\
\text { Form }\end{array}$ & $\begin{array}{l}\text { Testing } \\
\text { Methodologies }\end{array}$ & $\begin{array}{l}\text { Test program may } \\
\text { not adequate bound } \\
\text { various sources of } \\
\text { uncertainty }\end{array}$ & $\begin{array}{l}\text { Need to document uncertainties from } \\
\text { the various tests }\end{array}$ & $\begin{array}{l}\text { Precisions and biases of } \\
\text { the test results } \\
\text { Round robin results/inter- } \\
\text { and intra-lab variability }\end{array}$ & $\begin{array}{l}\text { Test data with } \\
\text { uncertainties } \\
\text { documented }\end{array}$ \\
\hline
\end{tabular}




\begin{tabular}{|c|c|c|c|c|c|c|}
\hline Label & Group & Element & $\begin{array}{c}\text { Risk or } \\
\text { Uncertainty }\end{array}$ & Need Description & $\begin{array}{c}\text { Key } \\
\text { Inputs/Predecessors }\end{array}$ & Outcomes/Successors \\
\hline PAM-3 & $\begin{array}{l}\text { Waste } \\
\text { Form }\end{array}$ & $\begin{array}{l}\text { Testing } \\
\text { Methodologies }\end{array}$ & $\begin{array}{l}\text { True release is } \\
\text { outside the allowable } \\
\text { range from the PA } \\
\text { assessment } \\
\text { Off normal condition } \\
\text { under which the } \\
\text { waste form performs } \\
\text { in a way not } \\
\text { predicted by the } \\
\text { model }\end{array}$ & $\begin{array}{l}\text { Evaluation of accidents/incidents } \\
\text { [NOTE: Two types of off normal } \\
\text { conditions. Experiments and } \\
\text { conditions that you may want to look } \\
\text { at to increase understanding. } \\
\text { Experiments and conditions that are } \\
\text { accounted for in the PA ] }\end{array}$ & $\begin{array}{l}\text { Definition of off normal } \\
\text { conditions } \\
\text { Acceptable model capable } \\
\text { of the evaluation } \\
\text { Process knowledge }\end{array}$ & $\begin{array}{l}\text { Confidence in the waste } \\
\text { form behavior } \\
\text { Test results to support } \\
\text { development of } \\
\text { bounding conditions }\end{array}$ \\
\hline PAM-4 & $\begin{array}{l}\text { Waste } \\
\text { Form }\end{array}$ & $\begin{array}{l}\text { Waste Form } \\
\text { Development }\end{array}$ & $\begin{array}{l}\text { Insufficient } \\
\text { understanding of the } \\
\text { key chemical, } \\
\text { physical, radiological } \\
\text { properties that impact } \\
\text { COC release } \\
\text { mechanism and } \\
\text { performance to make } \\
\text { decisions }\end{array}$ & $\begin{array}{l}\text { Need to know those } \\
\text { chemical/physical radiological } \\
\text { properties that impact COC release } \\
\text { mechanisms and performance } \\
\text { Need a theoretical understanding, } \\
\text { body of evidence, modeling and test } \\
\text { program that provides the needed } \\
\text { information. }\end{array}$ & $\begin{array}{l}\text { Data on the waste form } \\
\text { matrix } \\
\text { Any available information } \\
\text { on interactions between } \\
\text { matrix and COCs } \\
\text { Disposal and } \\
\text { environmental system } \\
\text { definition } \\
\text { Consensus test methods }\end{array}$ & $\begin{array}{l}\text { Agreed upon list of } \\
\text { properties that are key to } \\
\text { the COC release } \\
\text { mechanism } \\
\text { Appropriate } \\
\text { models/confirmation of } \\
\text { models for use in testing } \\
\text { and performance } \\
\text { assessment }\end{array}$ \\
\hline PAM-5 & $\begin{array}{l}\text { Waste } \\
\text { Form }\end{array}$ & $\begin{array}{l}\text { Testing } \\
\text { Methodologies }\end{array}$ & $\begin{array}{l}\text { Waste form } \\
\text { environment } \\
\text { interactions (e.g., } \\
\text { water and air, } \\
\text { disposal system, } \\
\text { other waste form co } \\
\text { disposed) are not } \\
\text { adequately } \\
\text { understood }\end{array}$ & $\begin{array}{l}\text { Need test methods to characterize } \\
\text { interactions with the disposal } \\
\text { environment over time and define } \\
\text { models }\end{array}$ & $\begin{array}{l}\text { Defined disposal } \\
\text { environment, inc. waste } \\
\text { forms (including } \\
\text { characterization of the } \\
\text { disposal site) } \\
\text { Definitions of off normal } \\
\text { conditions } \\
\text { Existing aging, transport, } \\
\text { thermodynamic and kinetic } \\
\text { models } \\
\text { Existing testing } \\
\text { methodologies }\end{array}$ & $\begin{array}{l}\text { Data to support model } \\
\text { development/definition } \\
\text { Input into the PA }\end{array}$ \\
\hline PAM-6 & $\begin{array}{l}\text { Waste } \\
\text { Form }\end{array}$ & $\begin{array}{l}\text { Long-Term } \\
\text { Performance } \\
\text { Assessment }\end{array}$ & $\begin{array}{l}\text { Release Rate of } \\
\text { Waste Form as a } \\
\text { Function of Time }\end{array}$ & $\begin{array}{l}\text { Technically defensible model of the } \\
\text { release from the waste form in } \\
\text { response to the environmental } \\
\text { conditions in the context of a PA. } \\
\text { For example, perhaps includes a } \\
\text { model to evaluate the thermodynamic } \\
\text { and kinetic compatibility with the } \\
\text { disposal environment }\end{array}$ & Contaminant release model & $\begin{array}{l}\text { Provides estimated } \\
\text { release from waste form } \\
\text { (to be refined) } \\
\text { Input from waste form } \\
\text { selection }\end{array}$ \\
\hline
\end{tabular}




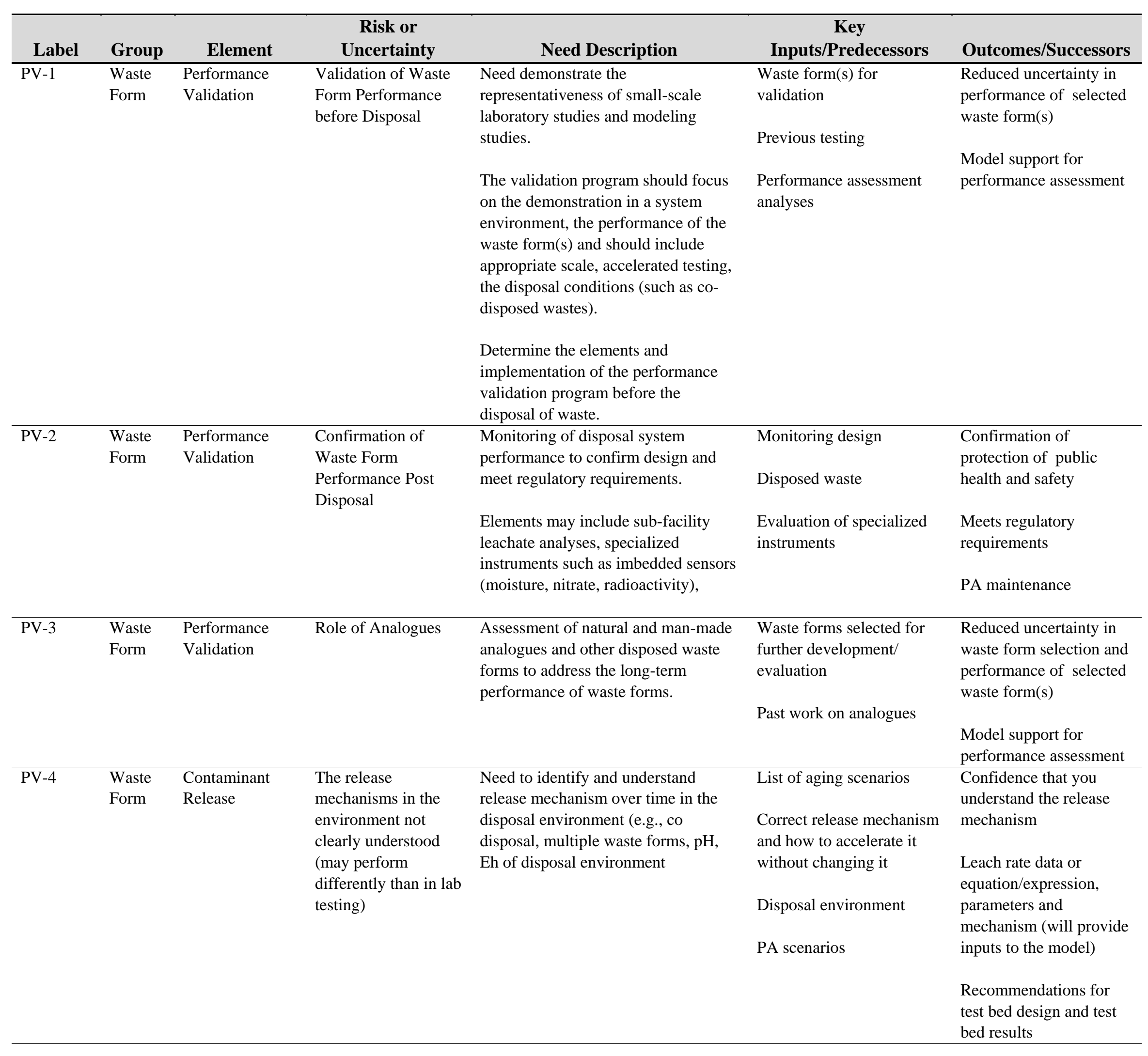




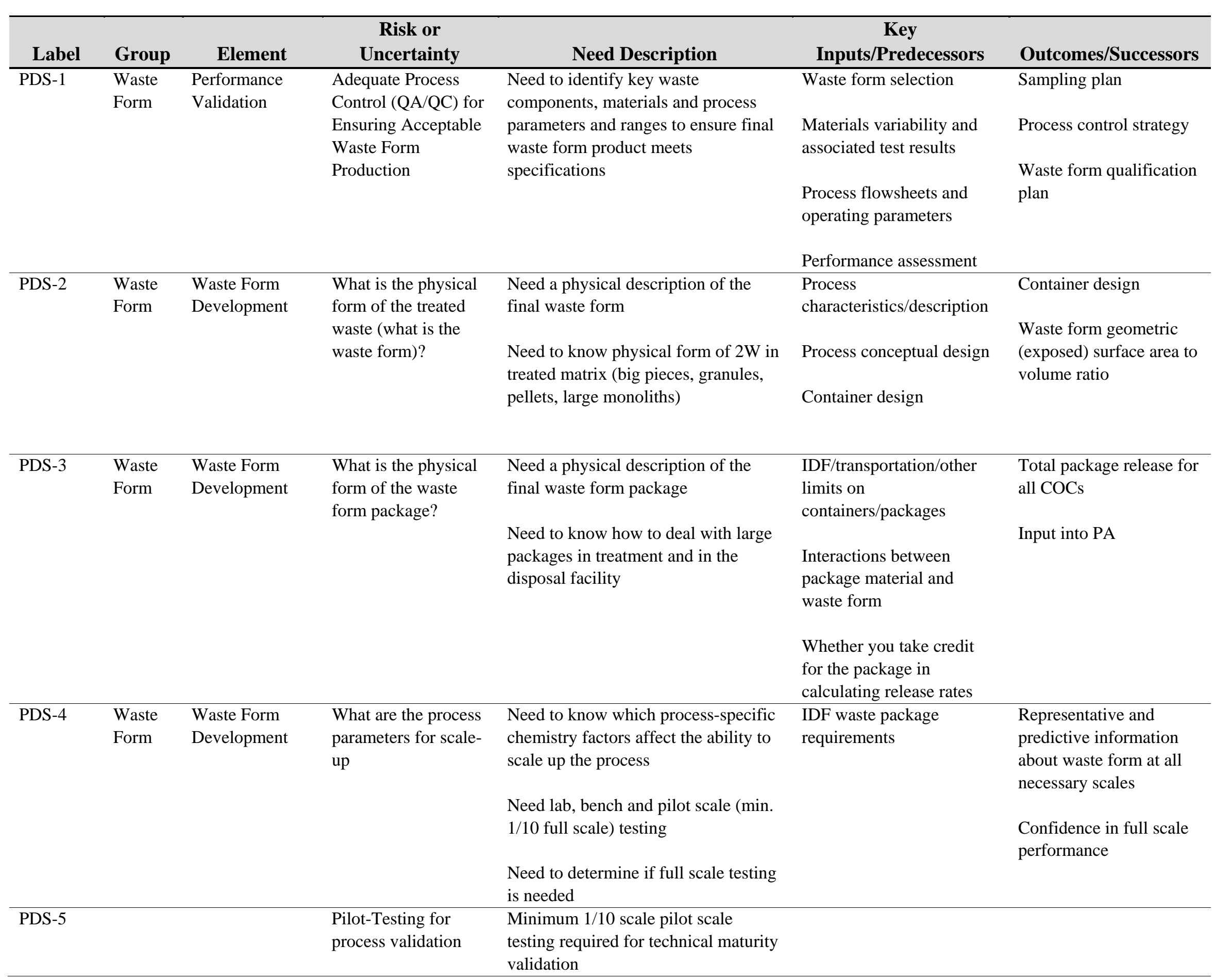




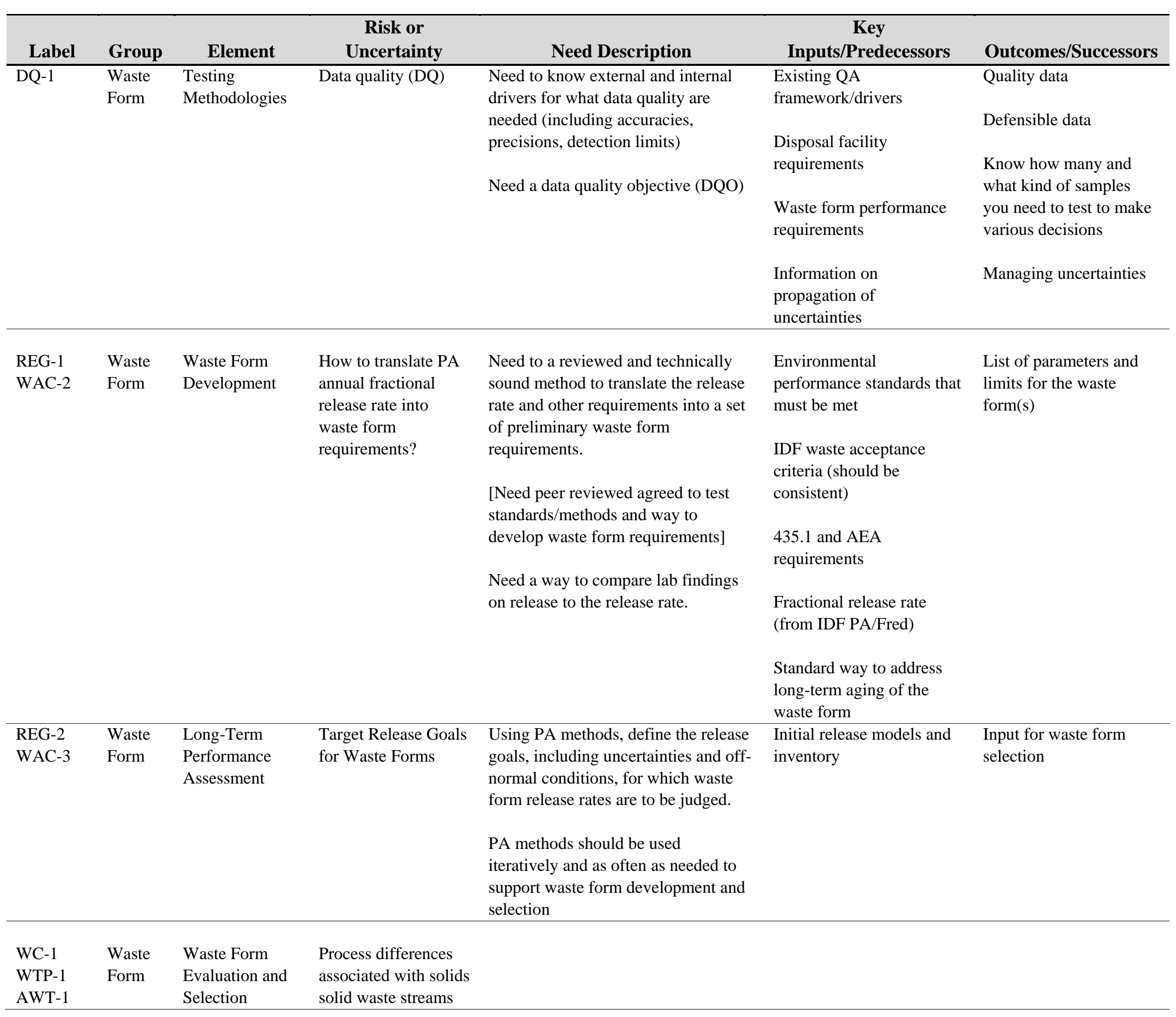




\begin{tabular}{|c|c|c|c|c|c|c|}
\hline & & & Risk or & & Key & \\
\hline Label & Group & Element & Uncertainty & Need Description & Inputs/Predecessors & Outcomes/Successors \\
\hline $\begin{array}{l}\text { WC-2 } \\
\text { SIM-4 }\end{array}$ & $\begin{array}{l}\text { Waste } \\
\text { Form }\end{array}$ & $\begin{array}{l}\text { Waste Form } \\
\text { Development }\end{array}$ & $\begin{array}{l}\text { Waste stream } \\
\text { compositions and } \\
\text { variations in } \\
\text { composition (i.e., } \\
\text { water content, } \\
\text { contaminant } \\
\text { composition both } \\
\text { hazardous and } \\
\text { radioactive, bulk and } \\
\text { minor chemical } \\
\text { COCs that might } \\
\text { impact waste form } \\
\text { and properties } \\
\text { important to } \\
\text { performance) }\end{array}$ & $\begin{array}{l}\text { Need an envelope (or range) for the } \\
\text { liquid waste stream and for the carbon } \\
\text { beds and for the silver mordenite } \\
\text { Need an envelope for the physical } \\
\text { characteristics of the wastes to be } \\
\text { treated (e.g. big pieces, other?) } \\
\text { Need to test the waste form over a } \\
\text { range of expected compositions }\end{array}$ & $\begin{array}{l}\text { Waste composition } \\
\text { Waste chemical, physical } \\
\text { and radiological properties, } \\
\text { physical forms, } \\
\text { characterization and range } \\
\text { (Coming from flowsheets) }\end{array}$ & $\begin{array}{l}\text { Waste forms that can } \\
\text { handle the range of } \\
\text { variability } \\
\text { Surrogates } \\
\text { Rad and nonrad simulant } \\
\text { compositions }\end{array}$ \\
\hline $\begin{array}{l}\text { WC-3 } \\
\text { TI-3 }\end{array}$ & $\begin{array}{l}\text { Waste } \\
\text { Form }\end{array}$ & $\begin{array}{l}\text { Waste Form } \\
\text { Evaluation and } \\
\text { Selection }\end{array}$ & $\begin{array}{l}\text { Tertiary waste from } \\
2^{\text {nd }} \text { waste form } \\
\text { creation }\end{array}$ & $\begin{array}{l}\text { Identify impacts (environmental, } \\
\text { programmatic, and cost) of tertiary } \\
\text { wastes associated with each } \\
\text { secondary waste form process (types, } \\
\text { amounts, compositions, variability, } \\
\text { uncertainness, treatment } \\
\text { requirements, disposal pathways, } \\
\text { costs) }\end{array}$ & $\begin{array}{l}\text { preliminary design } \\
\text { material balance } \\
\text { flowsheet } \\
\text { volume } \\
\text { available disposition routes } \\
\text { (if any) }\end{array}$ & $\begin{array}{l}\text { no orphan wastes } \\
\text { ability to get permits } \\
\text { information needed to } \\
\text { verify complete } \\
\text { evaluation of the system }\end{array}$ \\
\hline $\begin{array}{l}\text { WC-4 } \\
\text { SIM-5 }\end{array}$ & $\begin{array}{l}\text { Waste } \\
\text { Form }\end{array}$ & $\begin{array}{l}\text { Waste Form } \\
\text { Development }\end{array}$ & $\begin{array}{l}\text { Basing a lot of } \\
\text { decisions on } \\
\text { predicted flowsheet } \\
\text { information because } \\
\text { there's not actual } \\
\text { stream composition } \\
\text { data }\end{array}$ & $\begin{array}{l}\text { Need an agreed upon way to manage } \\
\text { this risk through testing protocols } \\
\text { (e.g., use wider range of possible } \\
\text { composition ranges; run more } \\
\text { extensive stimulant tests, etc.) }\end{array}$ & $\begin{array}{l}\text { Decision on early LAW or } \\
\text { decision to carry both } \\
\text { pathways forward } \\
\text { Decision on supplemental } \\
\text { treatment (but can make a } \\
\text { lot of progress proceeding } \\
\text { on WTP in the meantime) } \\
\\
\text { Target composition(s) and } \\
\text { agreed upon range(s) Need } \\
\text { to pin down the predicted } \\
\text { flowsheet info/variability } \\
\text { for WTP and any } \\
\text { additional treatment }\end{array}$ & $\begin{array}{l}\text { Confidence that process } \\
\text { can handle the range of } \\
\text { compositions }\end{array}$ \\
\hline WC-5 & $\begin{array}{l}\text { Waste } \\
\text { Form }\end{array}$ & $\begin{array}{l}\text { Waste Form } \\
\text { Evaluation and } \\
\text { Selection }\end{array}$ & $\begin{array}{l}\text { Radiological controls } \\
\text { and associated design } \\
\text { considerations }\end{array}$ & $\begin{array}{l}\text { What is the radiologic profile of each } \\
\text { secondary waste stream (ETF waste is } \\
\text { different from ion exchange resins) } \\
\text { Define administrative controls to } \\
\text { manage ALARA and disposal } \\
\text { [NOT RELEVANT TO WASTE } \\
\text { FORM EVALUATION \& } \\
\text { SELECTION, OUT OF SCOPE, } \\
\text { because there will be admin controls } \\
\text { for processing and disposal] }\end{array}$ & & \\
\hline
\end{tabular}




\begin{tabular}{|c|c|c|c|c|c|c|}
\hline Label & Group & Element & $\begin{array}{c}\text { Risk or } \\
\text { Uncertainty } \\
\end{array}$ & Need Description & $\begin{array}{c}\text { Key } \\
\text { Inputs/Predecessors } \\
\end{array}$ & Outcomes/Successors \\
\hline & $\begin{array}{l}\text { Waste } \\
\text { Form }\end{array}$ & $\begin{array}{l}\text { Waste Form } \\
\text { Evaluation and } \\
\text { Selection }\end{array}$ & $\begin{array}{l}\text { What modeling is } \\
\text { needed }\end{array}$ & (See WF-1) & & \\
\hline & $\begin{array}{l}\text { Waste } \\
\text { Form }\end{array}$ & $\begin{array}{l}\text { Waste Form } \\
\text { Evaluation and } \\
\text { Selection }\end{array}$ & $\begin{array}{l}\text { Can waste form be } \\
\text { seen as a resource? }\end{array}$ & Unlikely & & \\
\hline & $\begin{array}{l}\text { Waste } \\
\text { Form }\end{array}$ & $\begin{array}{l}\text { Waste Form } \\
\text { Evaluation and } \\
\text { Selection }\end{array}$ & $\begin{array}{l}\text { Total system } \\
\text { evaluation- } \\
\text { pretreatment } \\
\text { implementation time }\end{array}$ & ??????? & & \\
\hline & $\begin{array}{l}\text { Waste } \\
\text { Form }\end{array}$ & $\begin{array}{l}\text { Waste Form } \\
\text { Development }\end{array}$ & $\begin{array}{l}\text { What modeling is } \\
\text { needed }\end{array}$ & [Captured above](See WF-1) & & \\
\hline & $\begin{array}{l}\text { Waste } \\
\text { Form }\end{array}$ & $\begin{array}{l}\text { Contaminant } \\
\text { Release }\end{array}$ & $\begin{array}{l}\text { Scale-up has the } \\
\text { same release profile } \\
\text { as small scale }\end{array}$ & $\begin{array}{l}\text { [Addressed previously in waste form } \\
\text { development chart](See TM-4) }\end{array}$ & & \\
\hline & $\begin{array}{l}\text { Waste } \\
\text { Form }\end{array}$ & $\begin{array}{l}\text { Contaminant } \\
\text { Release }\end{array}$ & $\begin{array}{l}\text { How do/what are the } \\
\text { detailed properties/ } \\
\text { parameters of the } \\
\text { waste form that } \\
\text { influence release } \\
\text { (lab- and process- } \\
\text { scale) }\end{array}$ & $\begin{array}{l}\text { [Addressed in waste form } \\
\text { development chart](See WF-1) }\end{array}$ & & \\
\hline & $\begin{array}{l}\text { Waste } \\
\text { Form }\end{array}$ & $\begin{array}{l}\text { Contaminant } \\
\text { Release }\end{array}$ & $\begin{array}{l}\text { How release } \\
\text { mechanisms and/or } \\
\text { properties change } \\
\text { over time }\end{array}$ & [Addressed in aging](See WFA-1) & & \\
\hline & $\begin{array}{l}\text { Waste } \\
\text { Form }\end{array}$ & $\begin{array}{l}\text { Contaminant } \\
\text { Release }\end{array}$ & $\begin{array}{l}\text { Adequate } \\
\text { understanding of } \\
\text { release mechanism is } \\
\text { needed }\end{array}$ & $\begin{array}{l}\text { [above, above](See WF-1, PAM-1, } \\
\text { PV-4) }\end{array}$ & & \\
\hline & $\begin{array}{l}\text { Waste } \\
\text { Form }\end{array}$ & $\begin{array}{l}\text { Contaminant } \\
\text { Release }\end{array}$ & $\begin{array}{l}\text { Which release } \\
\text { scenarios are } \\
\text { important }\end{array}$ & [Above](See WF-2) & & \\
\hline & $\begin{array}{l}\text { Waste } \\
\text { Form }\end{array}$ & $\begin{array}{l}\text { Testing } \\
\text { Methodologies }\end{array}$ & $\begin{array}{l}\text { What is the } \\
\text { fundamental } \\
\text { mechanism to model }\end{array}$ & $\begin{array}{l}\text { [See waste forms \& contaminant } \\
\text { release charts](See WF-1, PAM-4) }\end{array}$ & & \\
\hline
\end{tabular}

